\title{
Intensive Cultural Resources Survey of the Proposed City of Conroe Stewarts Creek Wastewater System Improvements Project, Conroe, Montgomery County, Texas
}

Jeffrey D. Owens

Jesse O. Dalton

Follow this and additional works at: https://scholarworks.sfasu.edu/ita

Part of the American Material Culture Commons, Archaeological Anthropology Commons, Environmental Studies Commons, Other American Studies Commons, Other Arts and Humanities Commons, Other History of Art, Architecture, and Archaeology Commons, and the United States History Commons

Tell us how this article helped you.

This Article is brought to you for free and open access by the Center for Regional Heritage Research at SFA ScholarWorks. It has been accepted for inclusion in Index of Texas Archaeology: Open Access Gray Literature from the Lone Star State by an authorized editor of SFA ScholarWorks. For more information, please contact cdsscholarworks@sfasu.edu. 
Intensive Cultural Resources Survey of the Proposed City of Conroe Stewarts Creek Wastewater System Improvements Project, Conroe, Montgomery County, Texas

Creative Commons License

(c) (1) (9)

This work is licensed under a Creative Commons Attribution-NonCommercial 4.0 International License 


\section{Intensive Cultural Resources Survey of the Proposed City of Conroe Stewarts Creek Wastewater System Improvements Project, Conroe, Montgomery County, Texas}

By:

Jeffrey D. Owens and Jesse O. Dalton

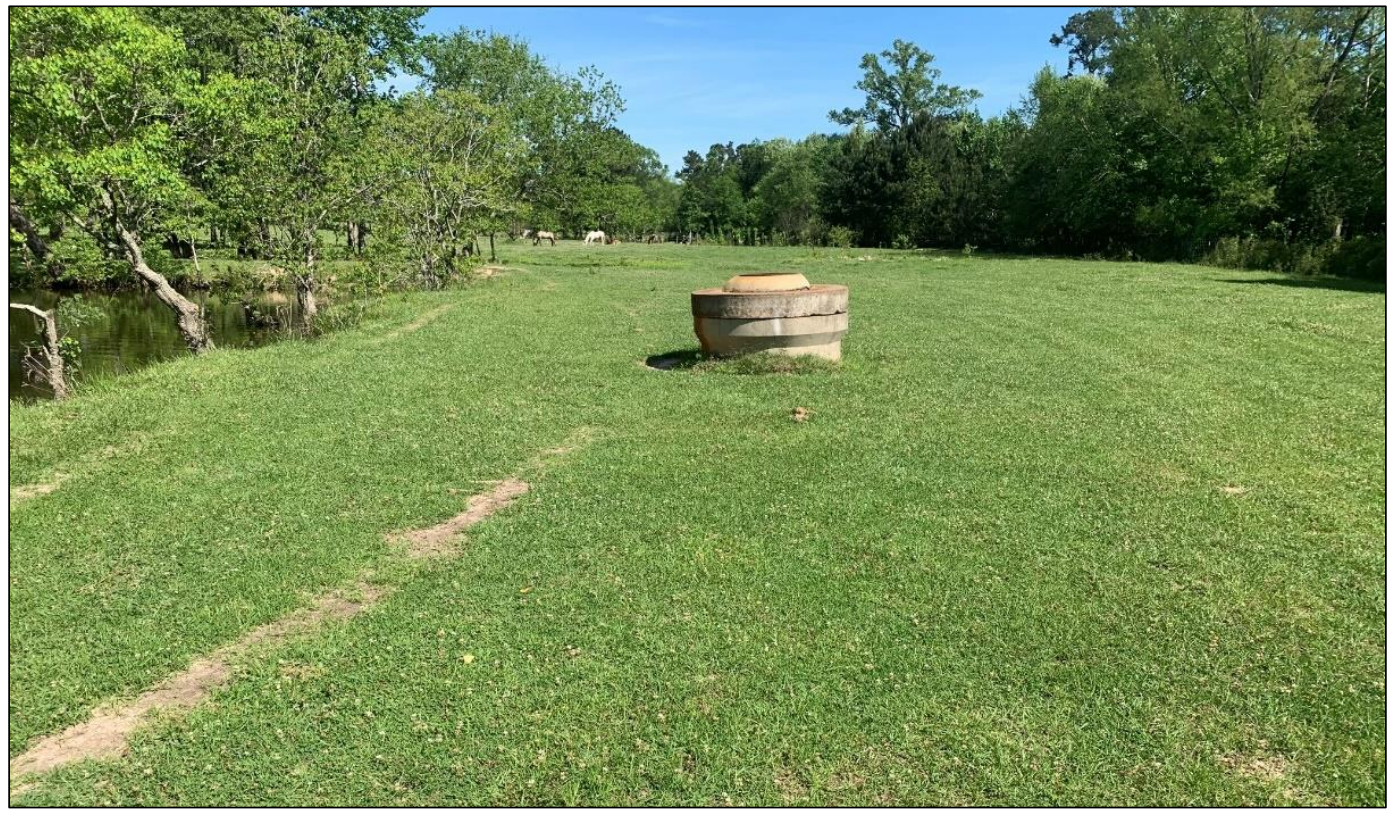

Texas Antiquities Permit No. 9336

LJA E225-0060

Prepared for:



LJA Engineering, Inc. Beaumont, Texas
Prepared by:

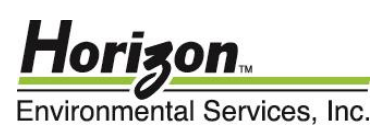

Horizon Environmental Services, Inc. Austin, Texas 



\title{
Intensive Cultural Resources Survey of the Proposed City of Conroe Stewarts Creek Wastewater System Improvements Project, Conroe, Montgomery County, Texas
}

By:

Jeffrey D. Owens and Jesse O. Dalton

Prepared for:

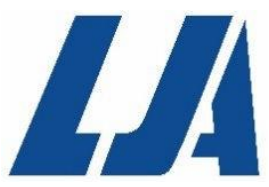

LJA Engineering, Inc.

2615 Calder Avenue, Suite 500

Beaumont, Texas 77702

\author{
Prepared by: \\ Horizon. \\ Environmental Services, Inc. \\ Horizon Environmental Services, Inc. \\ 1507 S. Interstate 35 \\ Austin, Texas 78741 \\ Jeffrey D. Owens, Principal Investigator \\ LJA E225-0060
}

Texas Antiquities Permit No. 9336

April 2020 



\section{MANAGEMENT SUMMARY}

Horizon Environmental Services, Inc. (Horizon) was selected by LJA Engineering, Inc. (LJA), on behalf of the City of Conroe, to conduct a cultural resources inventory and assessment for the proposed Stewarts Creek Wastewater System Improvements Project in Conroe, Montgomery County, Texas. The proposed undertaking would consist of rehabilitating and replacing approximately 2.1 kilometers ( 1.3 miles) of existing gravity sewer pipeline that runs along the western terraces of Stewarts Creek in the southeastern portion of Conroe. The segment of the existing sewer line proposed for rehabilitation and replacement runs along the western terraces of Stewarts Creek extending from Avenue M southward to an existing transmission line right-of-way (ROW) located southeast of the intersection of Foster Drive and Ed Kharbat Drive. For purposes of the cultural resources survey, the project area was considered to consist of a linear project corridor measuring 2.1 kilometers ( 1.3 miles) in length by 39.6 meters (130.0 feet) in width, covering a total area of 8.3 hectares (20.4 acres).

The proposed undertaking would be sponsored by the City of Conroe, which represents a political subdivision of the state of Texas. As such, the project falls under the jurisdiction of the Antiquities Code of Texas. In addition, the project may require the use of Nationwide Permits (NWP) issued by the US Army Corps of Engineers (USACE), Galveston District, for construction within or adjacent to any water features that meet the criteria for designation as "waters of the US" under Section 404 of the Clean Water Act and/or Section 10 of the Rivers and Harbors Act. As NWPs are federal permits, those portions of the overall project area located within the federal permit area would fall under the jurisdiction of Section 106 of the National Historic Preservation Act (NHPA) of 1966, as amended. As the proposed project represents a publicly sponsored undertaking, the project sponsor is required to provide the applicable federal agencies and the Texas Historical Commission (THC), which serves as the State Historic Preservation Office (SHPO) for the state of Texas, with an opportunity to review and comment on the project's potential to adversely affect historic properties listed on or considered eligible for listing on the National Register of Historic Places (NRHP) and/or for designation as State Antiquities Landmarks (SAL).

On April 1 to 2, 2020, Horizon archeologists Colene Knaub and Elizabeth Sefton, under the overall direction of Jeffrey D. Owens, Principal Investigator, performed an intensive cultural resources survey of the project area to locate any cultural resources that potentially would be impacted by the proposed undertaking. The survey was performed under Texas Antiquities 
Permit No. 9336. Horizon's archeologists traversed the archeological survey area on foot and thoroughly inspected the modern ground surface for aboriginal and historic-age cultural resources. The survey area consisted of an existing gravity sewer ROW running along the western terraces of Stewarts Creek. Most of the sewer line ROW consisted of broad, cleared areas characterized by short, manicured grasses, though some segments of the ROW appear not to have been regularly maintained and had become heavily overgrown with tall grasses, weeds, and wildflowers. Large concrete manholes providing access to the existing sewer line are spaced at regular intervals along this utility corridor. The ROW crosses Silverdale Drive, Foster Drive, and an electrical transmission line, and four large stock ponds are present adjacent to the ROW that involved extensive earth-moving activities within the project corridor. Prior disturbances within the existing sewer line corridor associated with construction and maintenance of the existing sewer line, stock ponds, intersecting roadways, and the transmission line have been extensive. Overall, ground surface visibility was generally poor $(<30 \%)$ due to dense vegetative ground cover.

In addition to pedestrian walkover, the Texas State Minimum Archeological Survey Standards (TSMASS) require a minimum of 10 shovel tests per 1.0 kilometer (16 shovel tests per 1.0 mile) for linear projects per 30.5-meter (100.0-foot) width of ROW, or fraction thereof. As such, a minimum of 42 shovel tests would be required within the 2.1-kilometer- (1.3-mile-) long by 39.6-meter- (130.0-foot-) wide project area. Horizon excavated 44 shovel tests during the survey, thereby exceeding the TSMASS requirements for a project area of this size. Shovel tests were staggered along either side of the existing sewer line as evidenced by the locations of manholes in an effort to test sediments that potentially had been less disturbed by the original construction of the sewer line.

Shovel testing typically revealed mixed brown to yellowish-brown sandy loam and sandy sediments with rare hematitic sandstone and oyster shell fragment inclusions. Mottling and mixing was observed in virtually every shovel test, suggesting that sediments within the survey corridor had been disturbed during the original construction of the sewer line. Given the extent of disturbance observed within the shovel tests excavated during the survey, it is Horizon's opinion that sediments within the proposed disturbance zone associated with rehabilitation and replacement of the existing sewer line have been disturbed to the depth of the existing pipeline and have minimal potential to contain any intact archeological deposits. Furthermore, a prior survey was conducted for the City of Conroe in 2001 that included mechanical deep testing, though this survey did not result in the documentation of any cultural resources along this segment of Stewarts Creek. As such, it is Horizon's opinion that the shovel testing was capable of evaluating the potential of the project area to contain prehistoric and historic-age cultural resources with the potential to meet the criteria of significance for inclusion in the NRHP and for designation as SALs.

No cultural resources, prehistoric or historic-age, were observed on the modern ground surface or within any of the shovel tests excavated within the project area. As no cultural resources were observed during the survey, no cultural resources were collected. Following completion of the project, all project records will be prepared for permanent curation at the Texas Archeological Research Laboratory (TARL). 
Based on the results of the survey-level investigations documented in this report, no potentially significant cultural resources would be affected by the proposed undertaking. In accordance with 36 CFR 800.4 , Horizon has made a reasonable and good-faith effort to identify historic properties within the project area. No cultural resources were identified within the project area that meet the criteria for designation as SALs according to 13 TAC 26 or for inclusion in the NRHP under 36 CFR 60.4. Horizon recommends a finding of "no historic properties affected," and no further archeological work is recommended in connection with the proposed undertaking. However, human burials, both prehistoric and historic, are protected under the Texas Health and Safety Code. In the event that any human remains or burial objects are inadvertently discovered at any point during construction, use, or ongoing maintenance in the project area, even in previously surveyed areas, all work should cease immediately in the vicinity of the inadvertent discovery, and the THC should be notified immediately. 



\section{TABLE OF CONTENTS}

Chapter

MANAGEMENT SUMMARY

1.0

2.0

INTRODUCTION

ENVIRONMENTAL SETTING.

2.1 Physiography and Hydrology 7

2.2 Geology and Geomorphology

2.3 Climate

2.4 Flora and Fauna

3.0 CULTURAL BACKGROUND

3.1 Paleolndian Period (ca. 10,000 to 6000 BC B.P.)

3.2 Archaic Period (ca. 6000 BC to AD 700 B.P.)

3.3 Early Ceramic Period (A.D. 100 to 600)

3.4 Late Prehistoric Period (ca. AD 700 to 1600 B.P.).

3.5 Historic Period (ca. 350 B.P. to Present)

Page

\section{..v} 1 7 7

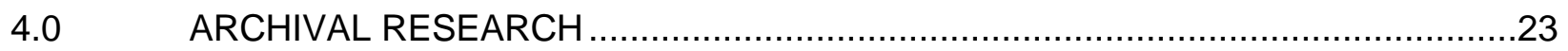

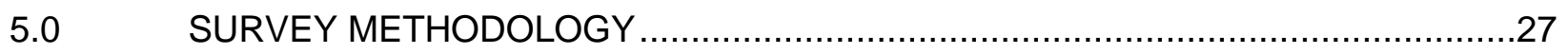

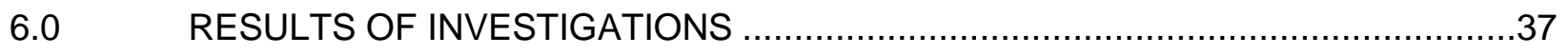



7.1 Conceptual Framework ............................................................... 39

7.2 Eligibility Criteria for Inclusion in the National Register of Historic Places .....40

7.3 Eligibility Criteria for Listing as a State Antiquities Landmark.......................41

$7.4 \quad$ Summary of Inventory Results ..................................................... 42

7.5 Management Recommendations.................................................. 43

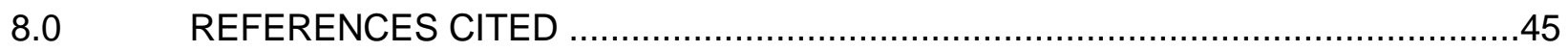

APPENDIX A: Shovel Test Data 


\section{LIST OF FIGURES}

Page

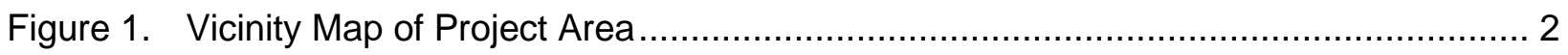

Figure 2. Location of Project Area on USGS Topographic Quadrangle ................................ 3

Figure 3. Location of Project Area on Aerial Photograph ................................................ 4

Figure 4. Soils Mapped within Project Area .................................................................. 9

Figure 5. Known Cultural Resources within 1.0 Mile of Project Area....................................25

Figure 6. View of Southern End of Project Area (Note Transmission Line) (Facing North) .....28

Figure 7. View of Southern End of ROW between STs CK02 and CK03 (Facing North) ........28

Figure 8. View of ROW South of Foster Drive (Facing Northeast) ...................................29

Figure 9. View of ROW North of Foster Drive (Facing North) ............................................29

Figure 10. View of ROW South of Silverdale Drive (Facing South-Southeast) ........................30

Figure 11. View of Stock Pond Near Southern End of ROW near ST CK02 (Facing West) .......30

Figure 12. View of Stock Pond Near ROW South of Foster Drive (Facing Northwest) .............31

Figure 13. View of Stock Pond North of Foster Drive (Facing South) ....................................

Figure 14. View of Concrete-Lined Banks of Stewarts Creek near Southern End of ROW (Facing Southeast)

Figure 15. Stewarts Creek between Silverdale Drive and Foster Drive (Facing East) ..............32

Figure 16. View of Stewarts Creek South of Silverdale Drive Bridge (Facing Southeast) ..........33

Figure 17. View of Stewarts Creek at Silverdale Drive Bridge (Facing Northeast)...................33

Figure 18. Locations of Shovel Tests Excavated within Project Area....................................34

\section{LIST OF TABLES}

Page

Table 1. Summary of Mapped Soils within Project Area ............................................... 8

Table 2. Summary of Known Cultural Resources within 1.0 Mile of Project Area.................24 


\subsection{INTRODUCTION}

Horizon Environmental Services, Inc. (Horizon) was selected by LJA Engineering, Inc. (LJA), on behalf of the City of Conroe, to conduct a cultural resources inventory and assessment for the proposed Stewarts Creek Wastewater System Improvements Project in Conroe, Montgomery County, Texas. The proposed undertaking would consist of rehabilitating and replacing approximately 2.1 kilometers ( 1.3 miles) of existing gravity sewer pipeline that runs along the western terraces of Stewarts Creek in the southeastern portion of Conroe. The segment of the existing sewer line proposed for rehabilitation and replacement runs along the western terraces of Stewarts Creek extending from Avenue M southward to an existing transmission line right-of-way (ROW) located southeast of the intersection of Foster Drive and Ed Kharbat Drive. For purposes of the cultural resources survey, the project area was considered to consist of a linear project corridor measuring 2.1 kilometers ( 1.3 miles) in length by 39.6 meters (130.0 feet) in width, covering a total area of 8.3 hectares (20.4 acres) (Figures 1 to 3 ).

The proposed undertaking would be sponsored by the City of Conroe, which represents a political subdivision of the state of Texas. As such, the project falls under the jurisdiction of the Antiquities Code of Texas. In addition, the project may require the use of Nationwide Permits (NWP) issued by the US Army Corps of Engineers (USACE), Galveston District, for construction within or adjacent to any water features that meet the criteria for designation as "waters of the US" under Section 404 of the Clean Water Act and/or Section 10 of the Rivers and Harbors Act. As NWPs are federal permits, those portions of the overall project area located within the federal permit area would fall under the jurisdiction of Section 106 of the National Historic Preservation Act (NHPA) of 1966, as amended. As the proposed project represents a publicly sponsored undertaking, the project sponsor is required to provide the applicable federal agencies and the Texas Historical Commission (THC), which serves as the State Historic Preservation Office (SHPO) for the state of Texas, with an opportunity to review and comment on the project's potential to adversely affect historic properties listed on or considered eligible for listing on the National Register of Historic Places (NRHP) and/or for designation as State Antiquities Landmarks (SAL).

On April 1 to 2, 2020, Horizon archeologists Colene Knaub and Elizabeth Sefton, under the overall direction of Jeffrey D. Owens, Principal Investigator, performed an intensive cultural resources survey of the project area to locate any cultural resources that potentially would be impacted by the proposed undertaking. The survey was performed under Texas Antiquities 




Figure 1. Vicinity Map of Project Area 
Intensive Cultural Resources Survey of the Proposed City of Conroe's

Stewarts Creek Wastewater System Improvements Project, Conroe, Montgomery County, Texas

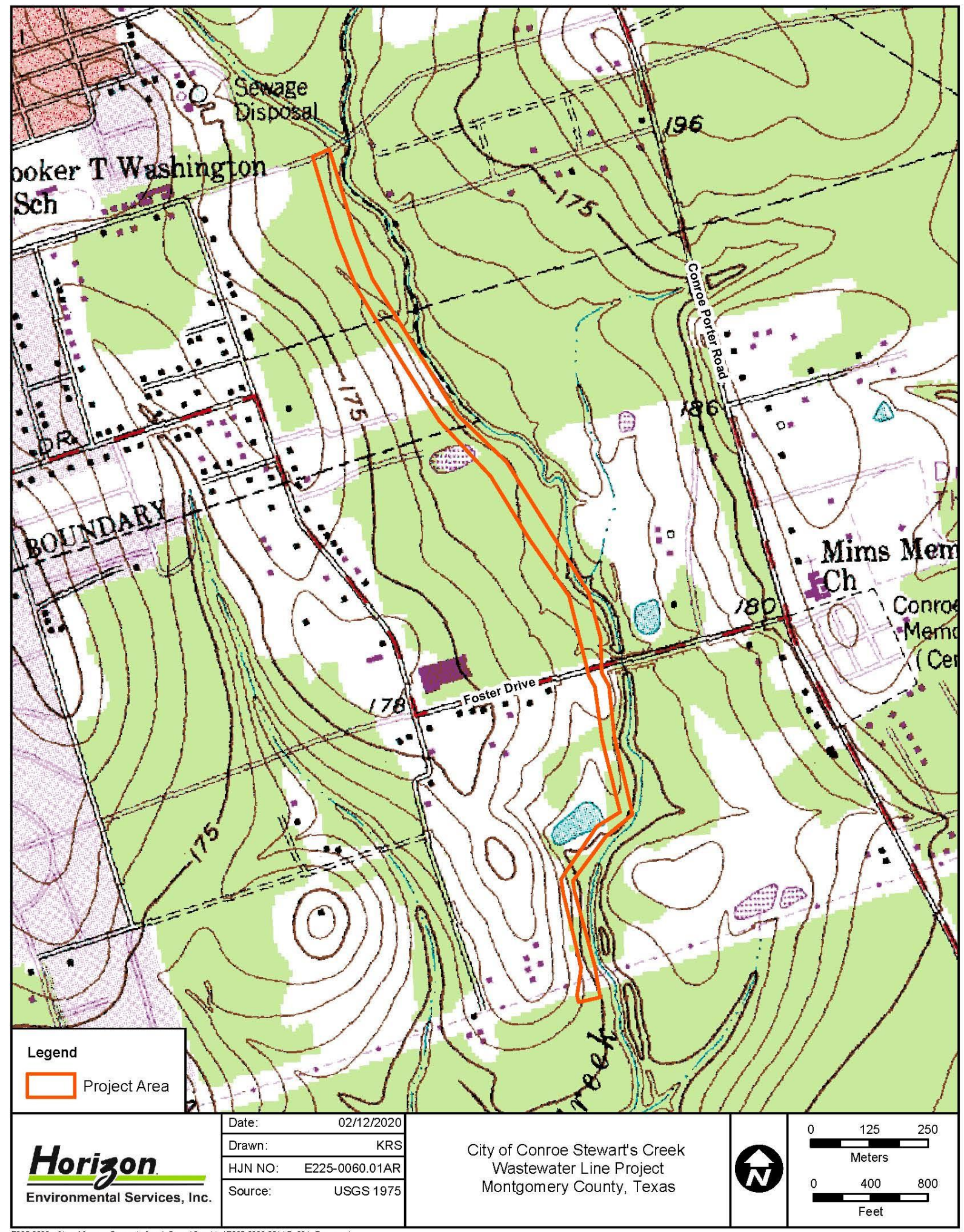

Figure 2. Location of Project Area on USGS Topographic Quadrangle 


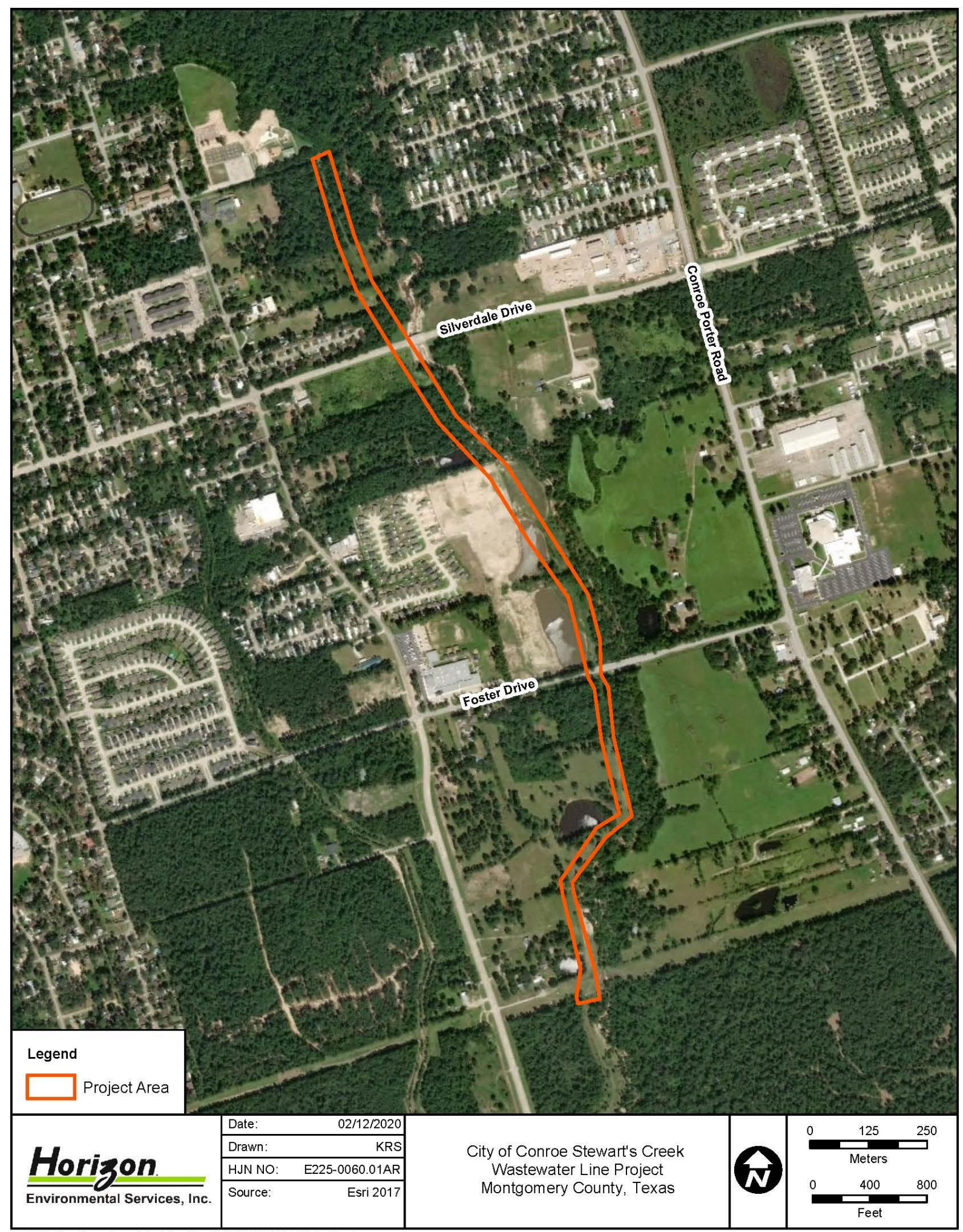

Figure 3. Location of Project Area on Aerial Photograph 
Permit No. 9336. The purpose of the survey was to locate any significant cultural resources that potentially would be impacted by the proposed undertaking. The cultural resources investigation consisted of an archival review, an intensive pedestrian survey of the project area, and the production of a report suitable for review by the SHPO in accordance with the THC's Rules of Practice and Procedure, Chapter 26, Section 26, and the Council of Texas Archeologists (CTA) Guidelines for Cultural Resources Management Reports.

Following this introductory chapter, Chapters 2.0 and 3.0 present the environmental and cultural backgrounds, respectively, of the project area. Chapter 4.0 describes the results of background archival research, and Chapter 5.0 discusses cultural resources survey methods. Chapter 6.0 presents the results of the cultural resources survey, and Chapter 7.0 presents cultural resources management recommendations for the project. Chapter 8.0 lists the references cited in the report, and Appendix A summarizes shovel test data. 



\subsection{ENVIRONMENTAL SETTING}

\subsection{Physiography AND Hydrology}

The project area is located in central Montgomery County, Texas. Montgomery County is situated on the Gulf Coastal Plain in southeastern Texas approximately 123.9 kilometers (77.0 miles) northwest of the Gulf of Mexico shoreline. The Gulf of Mexico represents a structural basin formed by lithosphere deformation. The Texas Coastal Plain, which extends as far north as the Ouachita uplift in southern Oklahoma and westward to the Balcones Escarpment, consists of seaward-dipping bodies of sedimentary rock, most of which are of terrigenous clastic origin, that reflect the gradual infilling of the basin from its margins (Abbott 2001). The Houston region is underlain by rocks and unconsolidated sediments that are quite young in a geological sense, ranging from modern to Miocene in age. These consist predominantly of a series of fluviodeltaic bodies arranged in an offlapped sequence, with interdigitated and capping eolian, littoral, and estuarine facies making up a relatively minor component of the lithology. Major bounding disconformities between these formations are usually interpreted to represent depositional hiatuses that occurred during periods of sea level low stand. The oldest rocks in this fill are of Late Cretaceous age. As a result of the geometry of basin filling, successively younger rock units crop out in subparallel bands from the basin margin toward the modern coastline.

Physiographically, the project area is located on the western terraces of Stewarts Creek within the West Fork of the San Jacinto River watershed. Stewarts Creek flows generally southwestward, discharging into the San Jacinto River roughly 5.3 kilometers (3.3 miles) southwest of the project area. The West Fork of the San Jacinto River flows southeastward across the coastal plain, combining with the East Fork of the San Jacinto river at Lake Houston. The San Jacinto River property flows southeastward from the Lake Houston dam and discharges into the Gulf of Mexico at Trinity Bay near Baytown. Drainage within the project area is locally to the east toward the channel of Stewarts Creek. Elevations within the project area slope down gradually to the south, ranging from approximately 45.7 to 50.2 meters (150.0 to 165.0 to feet) above mean sea level (amsl).

\subsection{GeOLOGY AND GEOMORPHOLOGY}

The project area is underlain by the Willis Formation (Qwc), a Pleistocene-age fluviodeltaic formation composed of clay, silt, sand, and siliceous gravels of granule to pebble size and some 
petrified wood (Shelby et al. 1968; USGS 2020). While debate about the temporal affiliations of and correlations among the deposits that underlie the major coastline terraces remains active, they are of little direct geoarcheological relevance because virtually all investigators agree that these deposits considerably predate the earliest demonstrated dates of human occupation in North America. Geomorphologically, the majority of the project area is characterized by the Hatliff-Pluck-Kian soil unit, which is composed of clayey and loamy alluvium of Holocene age (Table 1; Figure 4) (NRCS 2020). A very small sliver of the ROW at its southern terminus is characterized by the Conroe soil unit, which consists of clayey fluviomarine deposits.

\subsection{Climate}

Evidence for climatic change from the Pleistocene to the present is most often obtained through studies of pollen and faunal sequences (Bryant and Holloway 1985; Collins 1995). While the paleoclimatic history of the coastal region remains unclear, Bryant and Holloway (1985) present a sequence of climatic change for nearby east-central Texas that includes three separate climatic periods-the Wisconsin Full Glacial Period (22,500 to 14,000 B.P.), the Late Glacial Period (14,000 to 10,000 B.P.), and the Post-Glacial Period (10,000 B.P. to present). Evidence from the Wisconsin Full Glacial Period suggests that the climate in east-central Texas was considerably cooler and more humid than at present. Pollen data indicate that the region was more heavily forested in deciduous woodlands than during later periods (Bryant and Holloway 1985). The Late Glacial Period was characterized by slow climatic deterioration and a slow

Table 1. Summary of Mapped Soils within Project Area

\begin{tabular}{|c|c|c|c|}
\hline $\begin{array}{l}\text { NRCS } \\
\text { Soil Code }\end{array}$ & Soil Name & Parent Material & $\begin{array}{l}\text { Typical Profile } \\
\text { (inches) }\end{array}$ \\
\hline $\mathrm{CoC}$ & $\begin{array}{l}\text { Conroe loamy fine sand, } \\
0 \text { top } 5 \% \text { slopes }\end{array}$ & $\begin{array}{l}\text { Clayey marine deposits on } \\
\text { interfluves }\end{array}$ & $\begin{array}{l}\text { 0-25: Loamy fine sand } \\
\text { 25-31: Sandy clay loam } \\
\text { 31-78: Clay } \\
\text { 78-80: Sandy clay }\end{array}$ \\
\hline HatA & $\begin{array}{l}\text { Hatliff-Pluck-Kian complex, } \\
0 \text { to } 1 \% \text { slopes, } \\
\text { frequently flooded }\end{array}$ & $\begin{array}{l}\text { Clayey and loamy alluvium of } \\
\text { Holocene age on floodplains }\end{array}$ & $\begin{array}{l}\text { Hatliff: } \\
0-12: \text { Loam }(\mathrm{A}) \\
\text { 12-38: Fine sandy loam (Bw1) } \\
\text { 38-62: Fine sandy loam (Bw2) } \\
\text { 62-80: Fine sandy loam (Bg) } \\
\text { Pluck: } \\
0-6: \text { Fine sandy loam }(\mathrm{A}) \\
\text { 6-34: Loam (Bg1) } \\
\text { 34-60: Loam (Bg2) } \\
\text { 60-80: Loam (Bg3) } \\
\text { Kian: } \\
0-5: \text { Fine sandy loam }(\mathrm{A}) \\
\text { 5-26: Fine sandy loam }(\mathrm{Bw}) \\
\text { 26-55: Fine sandy loam (Bg1) } \\
\text { 55-80: Loamy fine sand (Bg2) }\end{array}$ \\
\hline
\end{tabular}

Source: NRCS (2020)

NRCS $=$ Natural Resources Conservation Service 
Intensive Cultural Resources Survey of the Proposed City of Conroe's

Stewarts Creek Wastewater System Improvements Project, Conroe, Montgomery County, Texas

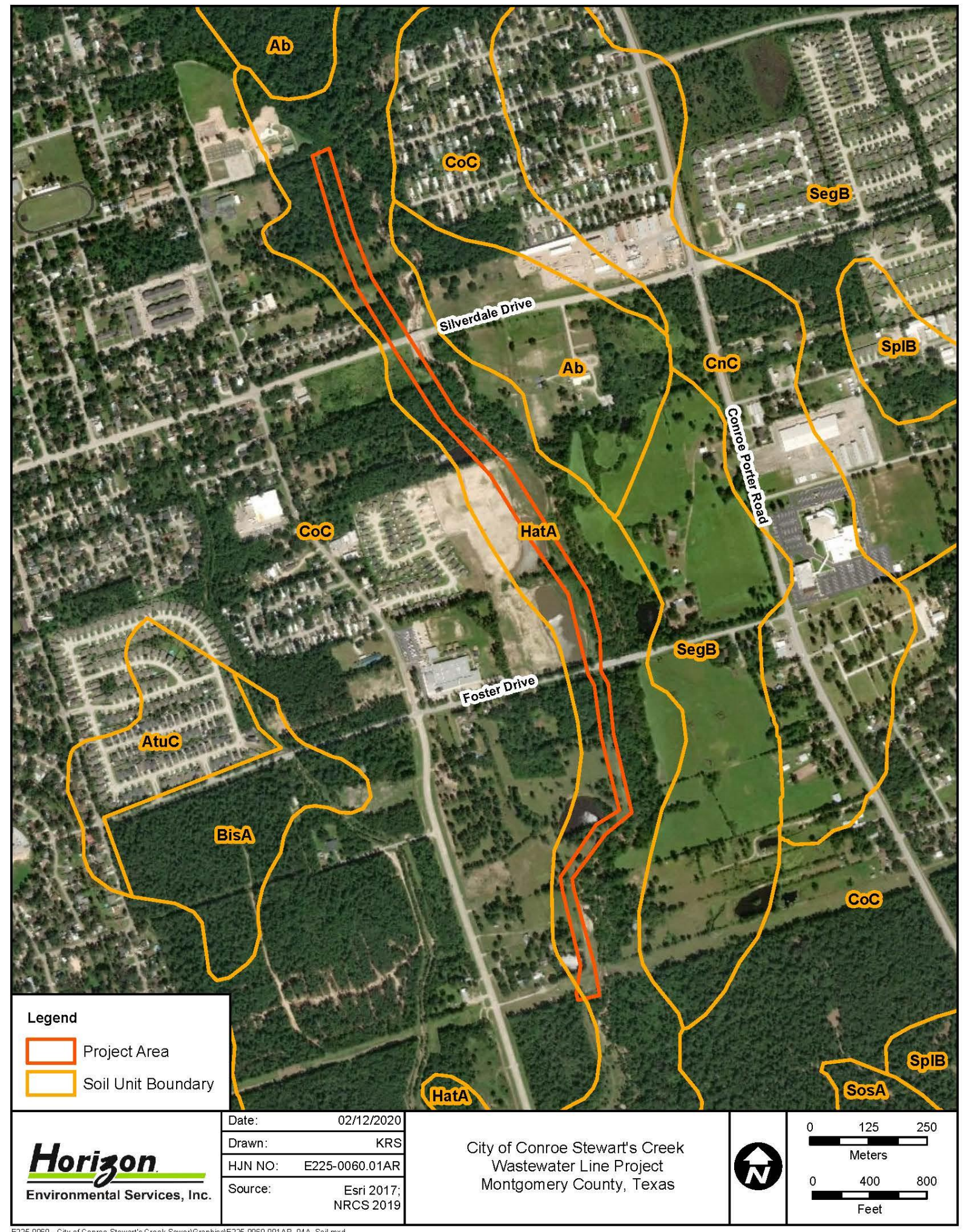

Figure 4. Soils Mapped within Project Area 
warming and/or drying trend (Collins 1995). In east-central Texas, the deciduous woodlands were gradually replaced by grasslands and post oak savannas (Bryant and Holloway 1985). During the Post-Glacial Period, the east-central Texas environment appears to have been more stable. The deciduous forests had long since been replaced by prairies and post oak savannas. The drying and/or warming trend that began in the Late Glacial Period continued into the midHolocene, at which point there appears to have been a brief amelioration to more mesic conditions lasting from roughly 6000 to 5000 B.P. Recent studies by Bryant and Holloway (1985) indicate that modern environmental conditions in east-central Texas were probably achieved by 1,500 years ago.

The modern climate of the upper Texas coast, including the region surrounding Houston, is classified as subtropical humid (Abbott 2001; Larkin and Bomar 1983), forming a transitional zone between the humid southeastern US and the semiarid to arid west. The climate reflects the influences of latitude, low elevation, and proximity to the Gulf of Mexico, which combine with the urban heat island formed by the tremendous concentration of asphalt and concrete to give the Houston area a notorious modern climate that is oppressively warm and moist throughout much of the year. As a result of proximity to the Gulf and the abundance of surface water, humidity in the early morning can approach $100 \%$ even on cloudless summer days, and it often exceeds $50 \%$ even on the warmest afternoons. Largely as a consequence of the relatively high humidity characteristic of the region, temperature patterns exhibit a moderate annual range and a modest diurnal range that increases slightly with distance from the coast. Average monthly high temperature ranges from a low of 17 to $19^{\circ} \mathrm{Celcius}\left({ }^{\circ} \mathrm{C}\right)\left(59\right.$ to $\left.63^{\circ} \mathrm{Fahrenheit}\left[{ }^{\circ} \mathrm{F}\right]\right)$ in January to a high of 38 to $40^{\circ} \mathrm{C}\left(89\right.$ to $96^{\circ} \mathrm{F}$ ) in August. Average monthly lows range from 4 to $9^{\circ} \mathrm{C}$ ( 38 to $47^{\circ} \mathrm{F}$ ) in January to 25 to $29^{\circ} \mathrm{C}\left(72\right.$ to $\left.79^{\circ} \mathrm{F}\right)$ in July and August. Annually, average low temperatures range from 15 to $21^{\circ} \mathrm{C}\left(56\right.$ to $65^{\circ} \mathrm{F}$ ), and average high temperatures range from 27 to $29^{\circ} \mathrm{C}$ ( 75 to $79^{\circ} \mathrm{F}$ ) (Abbott 2001; Larkin and Bomar 1983).

The Houston region experiences two precipitation peaks throughout the year (Abbott 2001). The first occurs in the late spring (i.e., May to June) due to the passage of infrequent cold fronts that spawn chains of powerful frontal thunderstorms. The second occurs in the late summer to early autumn (i.e., August to September) due to the incidence of tropical storms and hurricanes from the Atlantic and, occasionally, Pacific oceans. In contrast, winter and early spring are relatively dry, and high summer rainfall is dominated by convectional thunderstorms that are relatively brief and localized, albeit frequently intense. Average annual precipitation varies from a low of approximately 100.0 centimeters ( 40.0 inches) to a high of more than 132.0 centimeters (52.0 inches). Average monthly precipitation varies from less than 2.0 to 3.0 inches (5.0 to 8.0 centimeters) in March to more than 19.0 centimeters (7.5 inches) occurring locally on the coast during September. Almost all of the measurable precipitation falls as rain-snowfall is extremely rare, occurring in measurable amounts in only 1 in 10 years.

\subsection{FLORA AND FAUNA}

Montgomery County is situated near the southeastern edge of the Texas biotic province (Blair 1950), an intermediate zone between the forests of the Austroriparian and Carolinian provinces and the grasslands of the Kansas, Balconian, and Tamaulipan provinces. Some 
Intensive Cultural Resources Survey of the Proposed City of Conroe's

Stewarts Creek Wastewater System Improvements Project, Conroe, Montgomery County, Texas

species reach the limits of their ecological range within the Texas province. Four broad communities characterize the portion of the Texas biotic province that lies on the Gulf Coastal Plain: (1) coastal marsh/barrier island, (2) coastal prairie, (3) coastal gallery forest, and (4) pinehardwood forest (cf. Abbott 2001).

The coastal marsh/barrier island category includes well-drained, sandy, coastal environments and saline and freshwater wetlands in the coastal zone (Abbott 2001). Marsh vegetation is typical of areas that are seasonally wet and have substrates composed primarily of sands and silts, clays, or organic decomposition products. Vegetation assemblages are strongly controlled by texture, salinity, frequency and duration of inundation, and depth of the seasonal water table. Sandy, relatively well-drained, freshwater environments are typically dominated by little bluestem, switchgrass, Florida paspalum, and brownseed paspalum. Wetter environments are often dominated by marshhay cordgrass, seashore saltgrass, saggitaria, bulrushes, smooth cordgrass, seashore paspalum, seashore dropseed, olney bulrush, saltmarsh bulrush, saltmarsh aster, longtom, sprangletop, burhead, arrowhead, coastal waterhyssop, needlegrass rush, and other sedges and rushes. Slightly higher, better-drained environments are characterized by such taxa as seashore saltgrass, seashore paspalum, gulfdune paspalum, shoregrass, gulf cordgrass, red lovegrass, bushy sea-oxeye, and glasswort. A variety of fauna are characteristic of the shore zone. Important larger taxa include raccoon, nutria, alligators, turtles, swamp rabbit, and many birds, including ducks, geese, herons, and many smaller species. Aquatic taxa, including a wealth of fish and shellfish adapted to brackish to hypersaline conditions, are also important in the coastal marsh/barrier island zone.

The coastal prairie category consists primarily of grasses with minor amounts of forbs and woody plants in areas that are not saturated on a seasonal basis (Abbott 2001). This community is characteristic of upland areas and grades into the pine-hardwood forest to the north and east and into the coastal marsh/barrier island to the south. A wide variety of grasses are found in the prairie environments, but the principal taxa include big bluestem, little bluestem, indiangrass, eastern grama, switchgrass, brownseed paspalum, sideoats grama, silver bluestem, buffalograss, threeawn, and Texas wintergrass. Common forbs include Maximilian sunflower, Engelmann daisy, blacksalmon, penstemon, dotted gayfeather, bundleflower, yellow neptunia, snoutbean, prairie clover, tick clover, wild bean, western indigo, paintbrush, bluebonnet, ragweed, croton, milkweed, vetch, verbena, and winecup. Woody plants occurring in the coastal prairie include mesquite, honey locust, huisache, eastern baccharis, sesbania, live oak, elm, hackberry, bumelia, and coralberry. The frequency of trees increases dramatically as the coastal prairie grades into the pine-hardwood forest, forming an open woodland environment with common stands of hardwood trees and occasional pines. The coastal prairie is home to a diverse fauna, including coyote, white-tailed deer, skunks, cottontail rabbit, many small rodents, amphibians and reptiles, and a variety of permanent and migratory birds. Bison and pronghorn were also present at various times in the past.

The coastal gallery forest consists of diverse, principally deciduous trees and associated understory in floodplains and streams that traverse the outer coastal plain (Abbott 2001:26). Important taxa include water oak, pecan, poplar, American elm, cedar elm, sugarberry, ash, loblolly pine, post oak, cherrybark oak, mulberry, swamp chestnut oak, willow oak, sweetgum, 
hawthorn, dogwood, hickory, bois d'arc, sassafras cypress, willow, cottonwood, and sumac. Shrubs and vines such as mustang grape, greenbrier, yaupon, coralberry, possumhaw, elderberry, honeysuckle, dewberry, and blackberry are common in the understory, as are grasses such as little bluestem, big bluestem, and Indian grass. The fauna of the coastal gallery forest include white-tailed deer, opossum, raccoon, squirrel, turkey, a variety of small mammals and rodents, turtles, snakes, and many birds. Black bear was also present at various times in the past, and a number of fish and a few varieties of shellfish are present in the streams.

The pine-hardwood forest is characterized by a mix of coniferous and deciduous trees, including longleaf pine, shortleaf pine, loblolly pine, post oak, red oak, white oak, blackjack oak, willow oak, and live oak (Abbott 2001). Riparian environments often support larger deciduous trees like pecan, cottonwood, hickory, beech, and American elm. Understory vegetation varies from relatively open to quite dense and consists of shrubs, vines, forbs, and young trees. Common shrubs include acacia, yaupon, mayhaw, wild persimmon, myrtle, greenbrier, Virginia creeper, blackberry, dewberry, trumpet vine, gourd, and poison ivy. A variety of fauna is also present, including white-tailed deer, opossum, raccoon, squirrel, rabbit, mink, skunk, various small rodents, turtles, reptiles, and many different birds. Black bear was also present at times in the past, and bison and pronghorn were occasionally present in the transition zone to the coastal prairie environment. 


\subsection{CULTURAL BACKGROUND}

The project area is located within the Southeast Texas Archeological Region, a 21-county area extending from the Colorado River on the west to the Sabine River on the east and measuring about 200.0 kilometers (124.3-miles) inland from the Gulf of Mexico coastline. Much of the archeological record in Southeast Texas represents an interface between the Southern Great Plains and the Southeastern Woodlands (Aten 1983, 1984; Patterson 1995; Story 1990). Further distinctions are often made between the inland and coastal margin subregions of Southeast Texas. These two subregions are somewhat culturally distinct, and the inland subregion has a much longer chronological record. The coastal margin of Southeast Texas comprises a zone about 25.0 kilometers (15.5 miles) inland from the coast that covers the area influenced by Gulf tidal flows on the salinity of streams, lakes, and bays. Considerable ecological variability characterizes this subregion, including woodlands, coastal prairie, lakes, wetlands, marine coastline, and barrier islands. The inland subregion also encompasses considerable ecological diversity, including mixed woodlands, coastal prairies, and dense piney woods.

The human inhabitants of Southeast Texas practiced a generally nomadic hunting and gathering lifestyle throughout all of prehistory. While many of the same labels are used to denote Southeast Texas cultural/chronological periods, the timeframe and cultural characteristics of Southeast Texas culture periods are often different than in neighboring regions. For instance, the Archaic and Late Prehistoric time periods are different in Central and Southeast Texas, and Central Texas lacks the Early Ceramic period that has been defined for Southeast Texas.

Mobility and settlement patterns do not appear to have changed markedly through time in Southeast Texas. Inland sites are usually found near a water source, usually exhibit evidence of reoccupation through time, have well-defined intrasite activity areas, tend not to be associated with satellite activity sites or separate base camps, and exhibit a range of subsistence-related activities. Inland sites tend to contain modest pottery assemblages, fired clay balls (at some sites), abundant lithic material, and an absence of shell tools. Coastal sites tend to consist of multicomponent Rangia shell middens that contain few lithic artifacts, oyster shell tools, large quantities of pottery (in later cultural components), and numerous bone tools.

\subsection{Paleolndian Period (CA. 10,000 to 6000 BC B.P.)}

The initial human occupations in the New World can now be confidently extended back before 10,000 B.C. (Dincauze 1984; Haynes et al. 1984; Kelly and Todd 1988; Lynch 1990; 
Meltzer 1989). Evidence from Meadowcroft Rockshelter in Pennsylvania suggests that humans were present in Eastern North America as early as 14,000 to 16,000 years ago while more recent discoveries at Monte Verde in Chile provide unequivocal evidence for human occupation in South America by at least 12,500 years ago (Adovasio et al. 1990; Dillehay 1989, 1997; Meltzer et al. 1997). Most archeologists have historically discounted claims of much earlier human occupation during the Pleistocene glacial period. However, recent investigations of the Buttermilk Creek Complex in Bell County, Texas, have raised the possibility that a pre-Clovis culture may have been present in North America as early as 15,500 years ago (Waters et al. 2011).

The earliest generalized evidence for human activities in Southeast Texas is represented by the Paleolndian period (10,000 to 5000 B.C.) (Patterson 1995). This period coincided with ameliorating climatic conditions following the close of the Pleistocene epoch that witnessed the extinction of herds of mammoth, horse, camel, and bison. Cultures representing various periods within this stage are characterized by series of distinctive, relatively large, often fluted, lanceolate projectile points. These points are frequently associated with spurred end-scrapers, gravers, and bone foreshafts.

Paleolndian groups are often inferred to have been organized into egalitarian bands consisting of a few dozen individuals that practiced a fully nomadic subsistence and settlement pattern. Due to poor preservation of floral materials, subsistence patterns in Southeast Texas are known primarily through the study of faunal remains. Subsistence focused on the exploitation of small animals, fish, and shellfish, even during the Paleolndian period. There is little evidence in this region for hunting of extinct megafauna, as has been documented elsewhere in North America; rather, a broad-based subsistence pattern appears to have been practiced during all prehistoric time periods.

In Southeast Texas, the Paleolndian stage is divided into two periods based on recognizable differences in projectile point styles (Patterson 1995). These include the Early Paleolndian period (10,000 to 8000 B.C.), which is recognized based on large, fluted projectile points (i.e., Clovis, Folsom, Dalton, San Patrice, and Big Sandy), and the Late Paleolndian period (8000 to 5000 B.C.), which is characterized by unfluted lanceolate points (i.e., Plainview, Scottsbluff, Meserve, and Angostura). An extraordinary number of Clovis points in association with elephant tusks have been excavated from the McFaddin Beach site in Jefferson County, indicating an early Paleolndian occupation history; additionally, several isolated Folsom points have been found in situ at two sites in Harris County and on site $41 \mathrm{WH} 19$ in Wharton County (Ricklis 2003).

\subsection{Archaic Period (CA. 6000 BC to AD 700 B.P.)}

The onset of the Hypsithermal drying trend signaled the beginning of the Archaic period (5000 B.C. to A.D. 100) (Patterson 1995). This climatic trend marked the beginning of a significant reorientation of lifestyle throughout most of North America, but this change was far less pronounced in Southeast Texas. Elsewhere, the changing climatic conditions and corresponding decrease in the big game populations forced people to rely more heavily upon a diversified resource base composed of smaller game and wild plants. In Southeast Texas, however, this hunting and gathering pattern is characteristic of most of prehistory. The appearance of a more 
Intensive Cultural Resources Survey of the Proposed City of Conroe's

Stewarts Creek Wastewater System Improvements Project, Conroe, Montgomery County, Texas

diversified tool kit, the development of an expanded groundstone assemblage, and a general decrease in the size of projectile points are hallmarks of this time period. Material culture shows greater diversity during this broad cultural period, especially in the application of groundstone technology.

Traditionally, the Archaic period is subdivided into Early, Middle, and Late subperiods. In Southeast Texas, the Early Archaic period (5000 to 3000 B.C.) is marked by the presence of Bell, Carrollton, Morrill, Trinity, Wells, and miscellaneous Early Stemmed projectile points. The Bell point is the only type in this period that is closely associated with the Southern Plains. Many of the latter point types continue into the Middle Archaic period (3000 to 1500 B.C.) and several new types appear, including Bulverde, Lange, Pedernales, Williams, Travis, and probably the GaryKent series. The Late Archaic period (1500 B.C. to A.D. 100) is characterized by Gary, Kent, Darl, Yarbrough, Ensor, Ellis, Fairland, Palmillas, and Marcos points (Ricklis 2003).

In the western part of inland Southeast Texas, a Late Archaic mortuary tradition developed in the lower Brazos and Colorado river valleys and in the intervening area (Hall 1981; Patterson 1995). Organized burial practices actually started during the Middle Archaic period but reached full development in the Late Archaic with the use of exotic grave goods such as boatstones and bannerstones (probably used as atlatl weights), stone gorgets, corner-tang knives, stingray spines, shark teeth, and marine shell beads and pendants. Other burial practices included the systematic orientation of burial direction, body position, use of red ochre, and use of locally made grave goods, such as longbone implements and bone pins. Most burials are found in extended supine position, though some extended prone, and bundle burials are also known. Burial direction is usually consistent within single sites but varies from site to site. Patterson et al. (1993) report that at least 11 sites are associated with this mortuary tradition in Austin, Fort Bend, and Wharton counties. One notable Late Archaic mortuary site is the Ernest Witte site (41AU36), where two distinct cemeteries have yielded more than 206 bodies interred with an array of lithics, shell artifacts, and pedants (Ricklis 2003). Additionally, the Crestmont site in Wharton County, the Albert George site in Fort Bend County, and the Morhiss site in Victoria County all have led researchers to hypothesize that these Late Archaic cultures were beginning to systematically and communally inter their dead as a response to surges in population growth (Ricklis 2003). This population growth may have been brought on by the climatic changes in the early Holocene, such as an increase of floodplains from regional streams, which indirectly created locales with an abundance of food and other resources (Ricklis 2003).

\subsection{Early Ceramic Period (A.D. 100 to 600)}

The use of pottery did not start uniformly throughout Southeast Texas. Pottery manufacture appears to have diffused into this region from adjacent regions, primarily from the east along the coastal margin. Aten (1983:297) argues that pottery was being manufactured on the coastal margin of the Texas-Louisiana border by about 70 B.C., in the Galveston Bay area by about A.D. 100, in the western part of the coastal margin by about A.D. 300, and in the ConroeLivingston inland area by about A.D. 500. The practice of pottery manufacture appears to have progressed first along the coastal margin and then moved inland (Patterson 1995). Southeastern 
Texas ceramic chronologies are best known in the Galveston Bay area where Aten (1983) established a detailed chronological sequence.

The earliest ceramic periods in the Galveston Bay and neighboring Sabine Lake areas appear to be approximately contemporaneous with the earliest ceramic periods of the lower Mississippi Valley (Aten 1984). Early assemblages contain substantial quantities of Tchefuncte ceramics. In the Sabine Lake region, grog-tempered varieties of Baytown Plain and Marksville Stamped are common while grog-tempered ceramics do not occur in the Galveston Bay area 128.7 kilometers ( 80.0 miles) to the west until several hundred years later. With the principal exception of a few Tchefuncte ceramic types, other southern Louisiana ceramics are not found on the Gulf coast west of the Sabine Lake area.

The distinctive Woodland period archeological manifestation known as the Mossy Grove Culture/Tradition occupies the inland coastal plain and coastal margins that extend from the Brazos River Delta upwards to the Sabine River Delta (Ellis 2013). The Mossy Grove culture first appears in the archeological record around 2,500 years ago and consists of a sandy-paste ceramic technology similar to several styles of the Lower Mississippi River Valley cultures, such as Coles Creek and Fourche Maline (Ellis 2013). However, in contrast to the latter two cultures, Mossy Grove ceramics included rounded bottoms, floated surfaces, and thinner walls; overall, these wares typically demonstrate lower frequencies of decoration. Important Woodland components that contain Mossy Grove assemblages have been found at Jonas Short (41PK8), Crawford (41PK69), and site 41PK21; the latter site contains both Gary and Kent projectile points as well as evidence of Marksville Stamped ceramic sherds (Ellis 2013), hinting at regional trading patterns and an economic affinity of Mossy Grove with Lower Mississippi Valley cultures.

Goose Creek sandy-paste pottery was used throughout Southeast Texas and somewhat farther north in the Early Ceramic, Late Prehistoric, and the early part of the Historic periods (Aten 1984; Patterson 1995; Pertulla et al. 1995). The Goose Creek series is the primary utility ware throughout the prehistoric sequence in Southeast Texas, though it gives way to Baytown Plain for about 200 years during the transition between the Late Prehistoric and Historic periods before once again becoming predominant into the Historic period (Aten 1984). A minor variety, Goose Creek Stamped, occurs only in the Early Ceramic period (Aten 1983). Three other minor pottery types-Tchefuncte (Plain and Stamped), Mandeville, and O'Neal Plain variety Conway (Aten 1983) - were used only during the Early Ceramic period. The Mandeville and Tchefuncte types are characterized by contorted paste and poor coil wedging. Mandeville has sandy paste (like Goose Creek) while Tchefuncte paste has relatively little sand. Given their technological similarities, Mandeville and Tchefuncte may represent different clay sources rather than distinct pottery types (Patterson 1995). The bone-tempered pottery that characterizes ceramic assemblages elsewhere in Texas, such as the Caddo and Toyah cultures, is not common in Southeast Texas.

\subsection{Late Prehistoric Period (ca. AD 700 to 1600 B.P.)}

The onset of the Late Prehistoric period (A.D. 700 to 1500) (Patterson 1995) is defined by the appearance of the bow and arrow. Elsewhere in Texas, pottery also appears during the latter part of the Late Prehistoric period, but, as already discussed, ceramics appear earlier in Southeast 
Intensive Cultural Resources Survey of the Proposed City of Conroe's

Stewarts Creek Wastewater System Improvements Project, Conroe, Montgomery County, Texas

Texas. Along the coastal margin of Southeast Texas, use of the atlatl (i.e., spear thrower) and spear was generally discontinued during the Late Prehistoric period, though they continued to be used in the inland subregion along with the bow and arrow through the Late Prehistoric period (Ensor and Carlson 1991; Keller and Weir 1979; Patterson 1980, 1995; Wheat 1953). In fact, Patterson (1995:254) proposes that use of the bow and arrow started in Southeast Texas as early as the end of the Middle Archaic period using arrow points that consisted of marginally retouched unifacial flakes. In contrast, Prewitt (1981) argues for a generalized date of adoption of the bowand-arrow hunting system at about the same time (ca. A.D. 600) in Central and Southeast Texas. In Southeast Texas, unifacial arrow points appear to be associated with a small prismatic blade technology. Bifacial arrow point types include Alba, Catahoula, Perdiz, and Scallorn. A serial sequence for these point types has not been established in Southeast Texas, though Scallorn points appear to predate Perdiz points throughout the rest of Texas. The Late Prehistoric site, Mitchell Ridge (41GV66), is an example of an incipient bow and arrow culture that adapted and shifted to large game hunting subsistence strategies. This technocomplex shift is expressed by a change in its lithic technology and game procurement and processing toolkits (Ricklis 2003). Scallorn arrow points were replaced by smaller Perdiz arrow points (which are indicative of the Toyah horizon), and bison faunal remains began to appear in assemblages along with unifacial end scrapers, thin bifacial knives, and expanded base drills (Ricklis 2003). By A.D. 1300, an influx of bison had made their way down to the coastal prairies, and local populations responded through these technological adaptations.

Grog- (i.e., crushed-sherd-) tempered pottery was used in the Late Prehistoric and Protohistoric periods in Southeast Texas. The grog-tempered varieties include San Jacinto Plain and Baytown Plain variety Phoenix Lake. San Jacinto pottery contains a relatively small proportion of small-sized temper while Baytown Plain has larger amounts of sherd pieces that are often visible on vessel surfaces. As previously mentioned, sandy-paste Goose Creek pottery remained in use throughout the Late Prehistoric period. Rockport Plain and Asphaltum Coated pottery from the Central Texas Coast (Ricklis 1995) are found at a few sites in Southeast Texas during the Late Prehistoric and Protohistoric periods. Notable Late Prehistoric sites include the McGloin Bluff site (41SP11), where a large sample of Rockport ceramic sherds were found (approximately 28,275 specimens), and the Anaqua site (41JK8), where plain sandy-paste Goose Creek sherds were found with Scallorn arrow points, the style most often associated with the Rockport phase (Ricklis 2013). The presence of Rockport Phase ware at certain Spanish missions has linked this archeological ceramic culture with the historic Karankawa Indians of the South Texas Coast.

\subsection{Historic Period (CA. 350 B.P. to Present)}

The first European incursion into what is now known as Texas was in 1519 when Álvarez de Pineda explored the northern shores of the Gulf of Mexico. In 1528, Álvar Núñez Cabeza de Vaca crossed South Texas after being shipwrecked along the Texas Coast near Galveston Bay; however, European settlement did not seriously disrupt native ways of life until after 1700 . The first half of the 18th century was the period in which the fur trade and mission system, as well as the first effects of epidemic diseases, began to seriously disrupt the native culture and social systems. This process is clearly discernible at the Mitchell Ridge site, where the burial data 
suggest population declines and group mergers (Ricklis 1994), as well as increased participation on the part of the Native American population in the fur trade. By the time heavy settlement of Texas began in the early 1800s by Anglo-Americans, the indigenous Indian population was greatly diminished. The Alabama-Coushatta Indians who currently reside in Southeast Texas are migrants who were displaced from the east in the late 18th to early 19th centuries (Newcomb 1961).

By 1519, Spain had claimed much of the Texas Coast, stretching across the southeast Texas coastal and interior landscape, including present-day Montgomery, Galveston, Chambers, and Harris counties. Between the Neches and Trinity rivers there was a small tribe of Native Americans called the Orcoquisac by the Spaniards, who may have been akin to the Atakapan speakers who occupied western Louisiana and the inner-coastal Texas woodlands (Newcomb 1961; Swanton 1911). Little is known about the Texas sect of Atakapans, whose name is a Choctaw word for "man-eaters" (Newcomb 1961). Their language was likely of Tunican stock, but scant data are available about their linguistic origins (Swanton 1911). According to Newcomb, the Akokisas settled on the lower Trinity and San Jacinto rivers as well as the eastern shores of Galveston Bay; to the north lived a lesser known group, the Patiris, and, to their north, the Bidais (Newcomb 1961; Swanton 1911). Altogether, their population estimates are around 3,500 people (Newcomb 1961). The Galveston Bay focus likely practiced a hunter-gatherer subsistence strategy, for the saltwater flooding in the region would be cumbersome to any agricultural practices (Newcomb 1961).

It is possible that Cabeza de Vaca and/or members of the Narvaez expedition encountered the Atakapan communities as early as 1528, and it is also possible that La Salle's excursions in 1684 would have encountered these groups. However, the first documented European account of the Atakapans was left by French naval officer Simars de Bellisle in 1719 (Newcomb 1961). During his expedition, de Bellisle was stranded on the shore of Galveston Bay after a mishap on a supply run for fresh water, and he was taken captive and forcibly inducted into a tribe of Akokisas (Newcomb 1961). After taking a widowed wife, escaping to live with the Caddo tribe to the north, and living with a Hasinai woman, Angelica, the Frenchman eventually escaped native captivity and returned to Galveston Bay to work as a guide for Bernard de la Harpe, who led the first French expedition into present-day Oklahoma (Newcomb 1961). The Atakapans in southeastern Texas continued to trade deer and bison skins with the encroaching French settlers in Louisiana throughout the 1730s and 1740s until the Spanish Crown sent Captain Joaquin de Orobio Bazterra to investigate alleged French settlements in 1745 or 1746 (Henson 2010; Newcomb 1961). During this incursion, Bazterra visited several Orcoquisac villages along Spring Creek, a tributary of the San Jacinto River. He found no identifiable roads, maps, or any indications of French presence (Henson 2010; Newcomb 1961).

Around 1756, the Spanish erected an outpost near the mouth of the Trinity River in what is now Chambers County to combat the French presence in the region. This settlement consisted of a presidio named San Augustin de Ahumada and a mission named Nuestra Senora de la Luz (Ladd 2010). Atakapans were intermixed with 50 families of Tlascalan Indians brought in from central Mexico to help "pacify [them] more successfully" (Newcomb 1961). Collectively, this shortlived outpost was known as El Orcoquisac, named after the tribe. After a series of misfortunate 
Intensive Cultural Resources Survey of the Proposed City of Conroe's

Stewarts Creek Wastewater System Improvements Project, Conroe, Montgomery County, Texas

events that included mutinous internal fighting and ravaging by hurricanes, the fort outpost was abandoned by the Spanish in 1771 (Ladd 2010). The Bidais to the north were subjected to Spanish violence after trading firearms with the Lipan Apaches, who were enemies of the Spanish Crown (Newcomb 1961). A group of Atakapans settled somewhere along the Colorado River to the west of present-day Harris County in the mid-19th century, but they virtually disappeared from any records (Newcomb 1961). It is speculated that the remainder of the Atakapans who were not decimated by European epidemics or warfare either married into neighboring tribes, such as the displaced Alabama-Coushatta or the Caddo, or returned to Louisiana to join their linguistic and cultural kin, the eastern band of Atakapans (Newcomb 1961). Either way, all Atakapan speakers were gone from Texas by 1859 .

When Stephen F. Austin received his empresario grant in 1824 to allow 300 settlers to move to an allotment of 67,000 acres granted by the Mexican government, 42 Anglo-American families settled in what is now western Montgomery County (Long 2010a). The empresario contract specifically forbade Galveston Island and the Gulf shore to colonial settlement, so Austin's colonizers turned northward and northwestward to the lands that now comprise Harris and Montgomery counties (Henson 2010). During this time, there were no indications of Native American habitation in the former Atakapan lands (Henson 2010). By then, the local indigenous populations and social matrices had completely dissolved.

One of the first Anglo-American settlers in the area was filibuster, adventurer, and businessman Andrew Jackson Montgomery, who by 1823 had established a successful trading post on the lower Coushatta Trace between the Brazos and Trinity rivers (Montgomery 2010). Montgomery's business sat on the nexus of the famous Coushatta trail and the Lomo del Toro, another locally used Native American trail (Montgomery 2010). By 1827, Montgomery's business and settlement fostered a growing community, out of which grew the town of Montgomery; however, the actual town may have been named after William Montgomery, the father of two heroes of the Battle of San Jacinto (Grandy 1952). During the following decade, more settlers and businesses moved into the town and region, and in 1837, Montgomery County was carved from Washington County by an official decision made by the Republic of Texas Congress (Long 2010a). Originally, the county stretched from the Brazos River to the Trinity River and from the Old San Antonio Road on the north to the San Jacinto on the south, but Montgomery was subdivided amongst Grimes, Walker, San Jacinto, Madison, and Waller counties when Waller County was established in 1870 (Long 2010a). Being the largest town within the county, Montgomery was chosen as the county seat; other, smaller towns included Danville, Bay's Chapel, and Cincinnati. In 1838, the first log-structure courthouse was built, and in 1855, it was replaced by a large Greek Revival-style structure (Long 2010a). Also in 1838, Isaac Lemuel Gillespie Strickland, a pioneer Methodist missionary, was appointed by elder Littleton Fowler at the Texas Mission to organize a Methodist church between the Trinity and Brazos rivers. There, Rev. Strickland proselytized to the nascent settlement of Montgomery. By the 1850s, the Montgomery Academy had been established, which became one of the first prominent religious institutions in the region (Long 2010a).

By the onset of the Civil War, Montgomery County had transitioned from a subsistence farming-based economy to a slave-labor-based plantation economy that focused on cash crops, 
such as sugar and cotton. By 1860, the county contained 2,106 slaves out of a total population of 5,479, making it one of the largest slave-owning counties in the state (Grandy 1952). In early February 1861, the majority of the county's white male residents (318 of 416 ) voted in favor of Texas seceding from the Union (Long 2010a). Many citizens, which included almost every ablebodied man in the county, volunteered for the Confederate cause and joined regiments such as the Fourth Texas Regiment of Hood's Texas Brigade, Company H, and Terry's Texas Rangers; by the end of the war, more than three-quarters of the volunteer soldiers would be killed or wounded in action (Grandy 1952; Long 2010a). The costs and aftermath of the economic vacuum caused by the Civil War had drastic effects on the town of Montgomery. The slave-owning population suffered a huge decline in property values as slaves made up half of all taxable property in Montgomery County before the war (Long 2010a). Many ex-slaves became sharecroppers and tenant farmers.

There was no Freedman's Bureau, an agency initiated by President Abraham Lincoln whose goal was to educate ex-slaves and incorporate them into society, nor was there a federal garrison positioned in Montgomery County, and several acts of violence and intimidation toward African-American officials occurred during the Reconstruction period (Long 2010a). By 1872, due to the rise of the Ku Klux Klan violence across the South, the newly freed African-American population was disenfranchised and marginalized through threats, the use of the White Primary poll tax, and other racially targeted literacy tests (Long 2010a). By the 1880s, the local Democratic white elites had taken back the reigns of the post-war Republican-controlled government and ousted many African-Americans, who would not see positions in office until after the Civil Rights movements of the 1960s. Racial tensions were so high that white citizens who taught school to African-Americans or represented their legal rights were drowned, shot, or hung by the local Ku Klux Klan, mobs, and vigilante posses (Grandy 1952).

During the antebellum and Reconstruction periods, Montgomery County suffered a prolonged economic depression. However, this was alleviated somewhat by the introduction of the railroad. In 1871, the Houston and Great Northern Railroad laid its tracks across Montgomery County, which ignited a business boom for the towns that were adjacent to the lines. Willis, a town that sat right on the Houston and Great Northern Railroad, feuded with Montgomery after the war for contender for county seat, and many businesses and citizens moved from Montgomery to Willis after the war (Grandy 1952). However, Montgomery remained the county seat until a vote in 1889 moved it to Conroe, then a popular fledgling sawmill and timber town (Grandy 1952). Conroe was also chosen because it was positioned at the nexus of both the International-Great Northern and the newly built Gulf, Colorado, and Santa Fe Railway lines (Long 2010a). As a result of the feuds with Willis, especially during 1873, the town of Montgomery petitioned for a new railway, which was partially funded with citizen contributions (Grandy 1952). In 1877, a rightof-way was granted to the newly founded Central and Montgomery Railroad, and this independent line was maintained and operated from the 1880s until the 1940s (Grandy 1952). From 1879 to 1880, two more railroads were constructed-the Houston, East, and West Texas, and the Houston and Texas Central (Grandy 1952; Long 2010a). With these economic advances, the county's population boomed from a mere 6,483 citizens in 1870 to 10,154 citizens by 1880 . 
Intensive Cultural Resources Survey of the Proposed City of Conroe's

Stewarts Creek Wastewater System Improvements Project, Conroe, Montgomery County, Texas

Until the 1870s and early 1880s, Montgomery County suffered a dismal agricultural depression. Prices of cotton slumped during the late 1860s, and the plantation economy based on free slave labor had disappeared virtually overnight. Many plantations maintained a dependence on cotton and utilized the same African-American ex-slave labor force now under the guise of sharecropping, only to deplete the region's soils of nutrients. By the 1880s, overfarming, the lack of livestock rotation, and the introduction of the boll weevil took a toll on cotton production; in some areas, one acre of farmland produced as a little as one-third of a bale (Long 2010a). Other farmers turned to animal husbandry or switched to other crops such as corn and wheat, but cotton remained the largest export of the county until the early 1900s (Long 2010a).

Many farmers turned to tobacco in the 1880s as the county began to recover from its economic slump during the Reconstruction period. The town of Willis became known as a tobacco town and, at one point, had seven cigar factories employing hundreds of people (Grandy 1952). The favored and special variety was a fine-grade type known as Vuelta Abajo, and seeds were imported from Cuba every year (Grandy 1952). This successful industry prospered until the US government lifted a tariff on Cuban tobacco, which deflated the import taxes, making prices plummet; thereafter, no tobacco was grown in Montgomery County until the 1910s (Grandy 1952).

As the tobacco market subsided, the lumber industry began to boom. After the arrival of the railroads in the 1880s, the rich timber resources of the piney hardwoods of Montgomery County were harvested and exported to sawmills throughout the county (Grandy 1952). Before the Civil War, the cost of transporting natural resources out of the county over rough wagon roads made the timber industry unsustainable. With the emerging lumber boom came the establishment of 45 steam sawmills, and the ensuing systematic deforestation of the county would permanently alter the county's landscape and transform it from an area covered in thick pine forests to one that was more suitable for livestock and farming (Grandy 1952; Long 2010a). Lumber hubs included the towns of Bobville, Cowl Spur, Dobbin, Egypt, Fostoria, Honea, Karen, Keenan, Mostyn, Leonides, and Security (Long 2010a). Towns like Willis that had suffered from the collapse of the tobacco industry were saved by the wealth of the lumber industry. By the turn of the century, the population had grown from 11,765 in 1890 to 17,067 in 1900.

In 1932, while most counties were suffering the economic tribulations of the Great Depression, oil was discovered southeast of Conroe. Prior to this discovery, traces of oil and natural gas were known to occur in the county from exploration conducted by the Santa Fe Railroad Company, and later, leases were acquired by natural gas companies, but these were all ill-fated (Long 2010a). However, wildcatter and business adventurer George William Strake successfully tapped two oil wells in 1931 and 1932; the latter year produced a well that yielded more than 900 barrels daily (Long 2010a). Strake's discoveries sparked an oil boom, and by early 1932, a transient population of fortune-seekers had moved into Conroe (Grandy 1952). By early 1933, more than 100 wells would produce more than 25,000 barrels of oil per day, and at the end of the year, that number would double to more than 52,000 barrels per day (Long 2010a). Local infrastructure development in the county included public buildings, banks, paved roads, and new monuments erected from direct or indirect proceeds from the oil business (Long 2010a). By the second World War, Montgomery was one of the largest oil-producing counties in the entire nation, and Conroe, at one point in time, was considered the "third largest oil field in the United States" 
(Grandy 1952). Soon, the county saw the construction of several oil refineries, a carbon black manufacturing plant, and two creosoting plants (Grandy 1952). Population growth followed the boom, and the population jumped from 14,588 people in 1930 to 23,055 in 1940.

Today, Montgomery County still produces a vast amount of natural resources; in 2004, more than $1,000,000$ barrels of oil and 12,615,000 cubic feet of gas were produced in the county (Long 2010a). The Sam Houston National Forest, administered by the US Forest Service, is currently used for lumbering, grazing, oil production, and hunting (Long 2010b). The pine-wood forests and lumber industry in the area provided $\$ 73,108,000$ in local income for the resident population in the year 1994 (Long 2010b). The expansion of the greater Houston population through urbanization has been a direct impetus for the population growth in Montgomery County over the last decade. The current population is 590,925, and the county currently oversees six public school districts, several private schools, and more than 100 churches (Long 2010a). The lumber, agriculture, and oil industries dominate the local economy. Lake Conroe and Lake Woodlands are popular tourist destinations as well as the W. Goodrich Jones State Forest, which strives to protect the endangered red cockaded woodpecker (Etienne-Gray 2010). 


\subsection{ARCHIVAL RESEARCH}

Prior to initiating fieldwork, Horizon personnel reviewed the THC's online Texas Archeological Sites Atlas (TASA) and Texas Historic Sites Atlas (THSA), the National Park Service's (NPS) online National Register Information System (NRIS), and the Texas State Historical Association's (TSHA) The Handbook of Texas Online for information on previously recorded archeological sites and previous archeological investigations conducted within a 1.6kilometer (1.0-mile) radius of the archeological survey area. Based on this archival research, two previously recorded archeological sites, three cemeteries, and an isolated grave (the location of this grave is not known) are present within a 1.6-koleter (1.0-mile) radius of the project area (Table 2; Figure 5). No documented cultural resources, including any historic properties listed on the NRHP and/or designated as SALs, are located within or immediately adjacent to the boundaries of the project area. However, the location of the isolated grave, known as the Lee Allen grave, in not specifically known; rather, a large probable location area is indicated along Silverdale Drive west of the project area that was presumably estimated based on historical accounts.

Examination of historical US Geological Survey (USGS) topographic maps dating from 1959 to the present and aerial photographs dating from 1957 to the present indicate that no standing structures of potentially historic age (i.e., 50 years of age or older) are located within the project area. The surrounding area has been developed since before the mid-20th century.

Based on the TASA database, three prior cultural resources surveys have been conducted along the same segment of Stewarts Creek along which the current project are runs, including one linear survey in 1980 for an unidentified US Environmental Protection Agency (EPA) project, another linear survey in 1983 for an unidentified Texas Water Development Board (TWDB) project, and a third linear survey for a City of Conroe project in 2001 (Mason and Garcia-Herreros 2002). In addition, the area immediately surrounding the Foster Drive bridge over Stewarts Creek was surveyed in connection with a Federal Highway Administration (FHWA) project in 1996, and a proposed residential subdivision tract located off the northern side of Foster Drive on the western side of Stewarts Creek was surveyed in 2007 in connection with a development project funded by a US Department of Housing and Urban Development block grant. Notably, the 2001 survey (Mason and Garcia-Herreros 2002) included deep testing along the terraces of Conroe Creek, though no cultural resources were documented along this segment of the creek during this prior survey. 
Table 2. Summary of Known Cultural Resources within 1.0 Mile of Project Area

\begin{tabular}{|c|c|c|c|c|}
\hline $\begin{array}{c}\text { Site } \\
\text { No./Name }\end{array}$ & Site Type & $\begin{array}{c}\text { NRHP/SAL } \\
\text { Eligibility Status }{ }^{1}\end{array}$ & $\begin{array}{l}\text { Distance/Direction } \\
\text { from Project Area }\end{array}$ & $\begin{array}{l}\text { Potential to } \\
\text { be Impacted } \\
\text { by Project? }\end{array}$ \\
\hline \multicolumn{5}{|c|}{ Archeological Sites } \\
\hline 41MQ142 & $\begin{array}{l}\text { Historic-age trash dump } \\
\text { (undetermined historic) }\end{array}$ & Undetermined & 250.0 feet east & No \\
\hline $41 \mathrm{MQ334}$ & $\begin{array}{l}\text { Historic-age farmstead } \\
\text { (mid-19th to 20th } \\
\text { centuries) }\end{array}$ & $\begin{array}{l}\text { Determined } \\
\text { ineligible }\end{array}$ & 0.3 mile west & No \\
\hline \multicolumn{5}{|l|}{ Cemeteries } \\
\hline $\begin{array}{l}\text { Conroe } \\
\text { Memorial Park } \\
\text { Cemetery } \\
(\mathrm{MQ}-\mathrm{C} 011)\end{array}$ & Cemetery & $\mathrm{N} / \mathrm{A}$ & 0.3 mile east & No \\
\hline $\begin{array}{l}\text { Dorsey } \\
\text { Community } \\
\text { Cemetery } \\
\text { (MQ-C144) } \\
\end{array}$ & Cemetery & $N / A$ & $\begin{array}{l}0.9 \text { mile north- } \\
\text { northwest }\end{array}$ & No \\
\hline $\begin{array}{l}\text { Lee Allen } \\
\text { Grave }\end{array}$ & Cemetery & $\mathrm{N} / \mathrm{A}$ & Location unknown & Unknown \\
\hline $\begin{array}{l}\text { Oakwood } \\
\text { Cemetery } \\
\text { (MQ-C012) }\end{array}$ & Cemetery & $\mathrm{N} / \mathrm{A}$ & $\begin{array}{l}0.7 \text { mile north- } \\
\text { northwest }\end{array}$ & No \\
\hline
\end{tabular}

1 Determined eligible/ineligible $=$ Site determined eligible/ineligible by SHPO

Recommended eligible/eligible $=$ Site recommended as eligible/ineligible by site recorder and/or sponsoring agency but eligibility has not been determined by SHPO

Undetermined = Eligibility not assessed or no information available

NRHP National Register of Historic Places

SAL State Antiquities Landmark

SHPO State Historic Preservation Office 
Intensive Cultural Resources Survey of the Proposed City of Conroe's

Stewarts Creek Wastewater System Improvements Project, Conroe, Montgomery County, Texas

SENSITVE ARCHEOLOGICAL SITE LOCATION INFORMATION OMITTED

Figure 5. Known Cultural Resources within 1.0 Mile of Project Area 



\subsection{SURVEY METHODOLOGY}

On April 1 to 2, 2020, Horizon archeologists Colene Knaub and Elizabeth Sefton, under the overall direction of Jeffrey D. Owens, Principal Investigator, performed an intensive cultural resources survey of the project area to locate any cultural resources that potentially would be impacted by the proposed undertaking. The survey was performed under Texas Antiquities Permit No. 9336. Horizon's archeologists traversed the archeological survey area on foot and thoroughly inspected the modern ground surface for aboriginal and historic-age cultural resources. The survey area consisted of an existing gravity sewer ROW running along the western terraces of Stewarts Creek. Most of the sewer line ROW consisted of broad, cleared areas characterized by short, manicured grasses, though some segments of the ROW appear not to have been regularly maintained and had become heavily overgrown with tall grasses, weeds, and wildflowers. Large concrete manholes providing access to the existing sewer line are spaced at regular intervals along this utility corridor (Figures 6 to 10). The ROW crosses Silverdale Drive, Foster Drive, and an electrical transmission line, and four large stock ponds are present adjacent to the ROW that involved extensive earth-moving activities within the project corridor (Figures 11 to 13). The streambanks along most of the central and southern portions of Stewarts Creek have been contoured and covered in cement lining, though isolated sections of the creek have not been modified (Figures 14 to 17). Prior disturbances within the existing sewer line corridor associated with construction and maintenance of the existing sewer line, stock ponds, intersecting roadways, and the transmission line have been extensive. Overall, ground surface visibility was generally poor $(<30 \%)$ due to dense vegetative ground cover.

In addition to pedestrian walkover, the Texas State Minimum Archeological Survey Standards (TSMASS) require a minimum of 10 shovel tests per 1.0 kilometer (16 shovel tests per 1.0 mile) for linear projects per 30.5-meter (100.0-foot) width of ROW, or fraction thereof. As such, a minimum of 42 shovel tests would be required within the 2.1-kilometer- (1.3-mile-) long by 39.6-meter- (130.0-foot-) wide project area. Horizon excavated 44 shovel tests during the survey, thereby exceeding the TSMASS requirements for a project area of this size (Figure 18). Shovel tests were staggered along either side of the existing sewer line as evidenced by the locations of manholes in an effort to test sediments that potentially had been less disturbed by the original construction of the sewer line.

In general, shovel tests measured approximately 11.8 inches (30.0 centimeters) in diameter, and all sediments were screened through 0.25 -inch (6.35-millimeter) hardware cloth. The Universal Transverse Mercator (UTM) coordinates of all shovel tests were determined using 


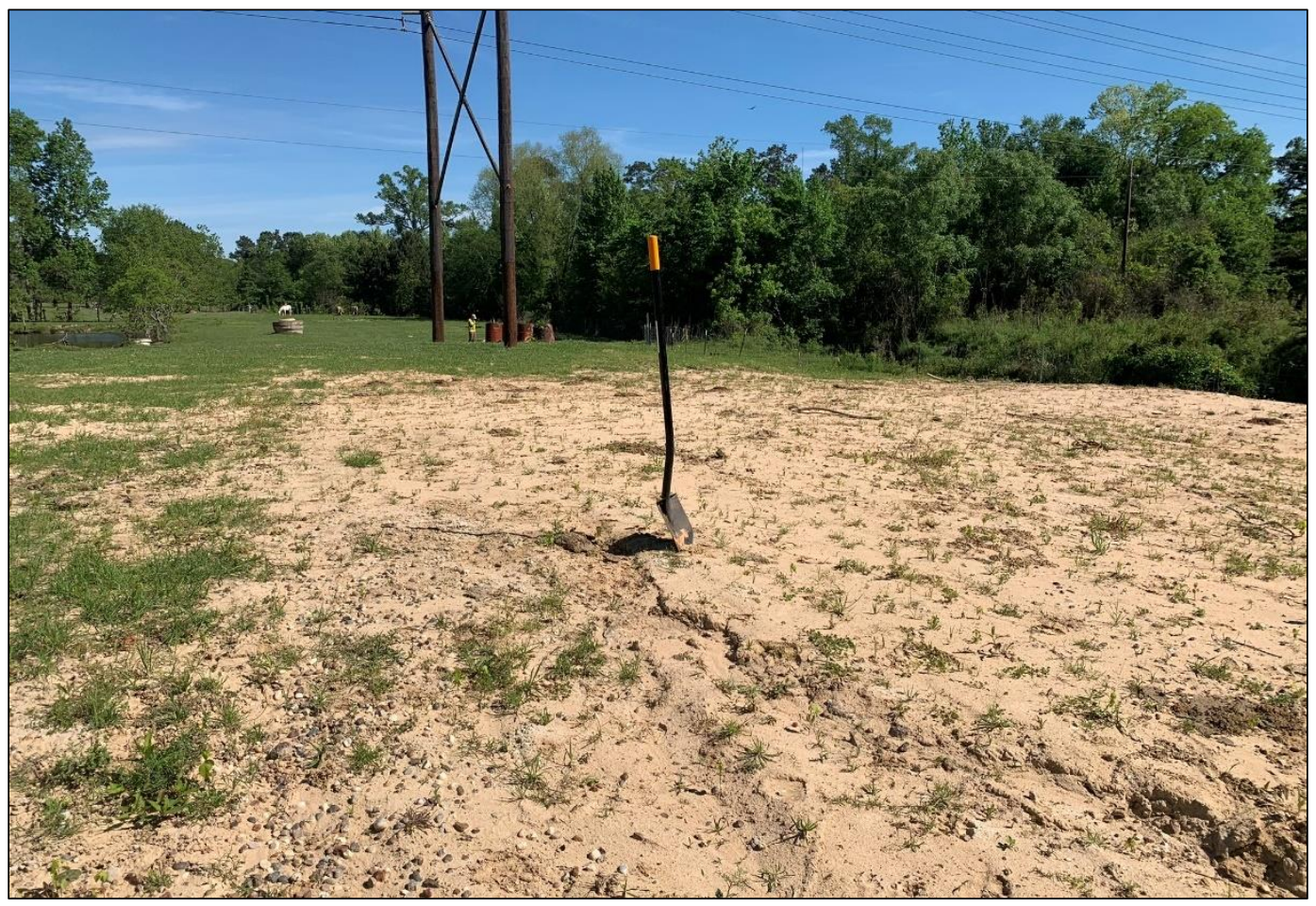

Figure 6. View of Southern End of Project Area (Note Transmission Line) (Facing North)

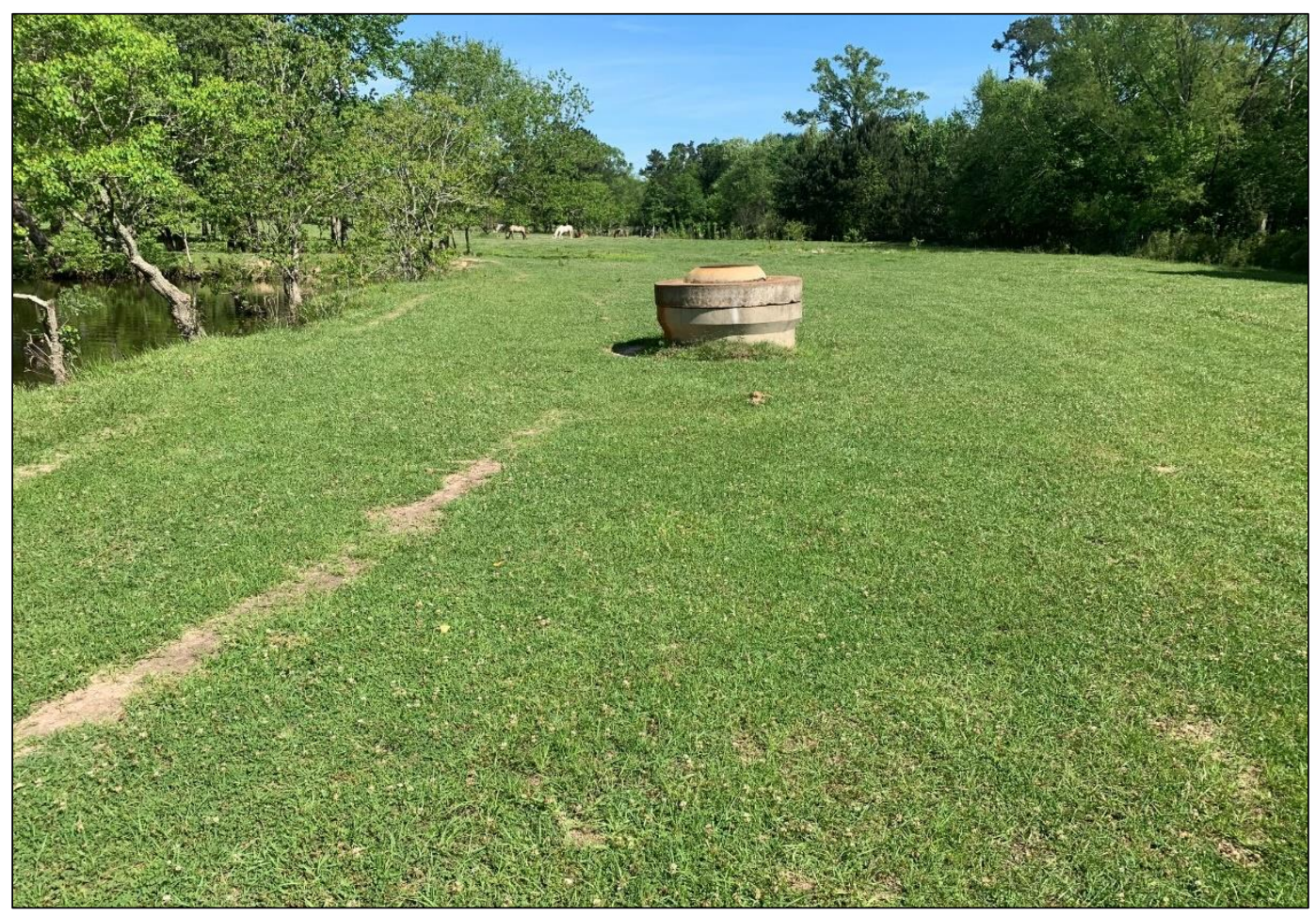

Figure 7. View of Southern End of ROW between STs CK02 and CK03 (Facing North) 
Intensive Cultural Resources Survey of the Proposed City of Conroe's

Stewarts Creek Wastewater System Improvements Project, Conroe, Montgomery County, Texas

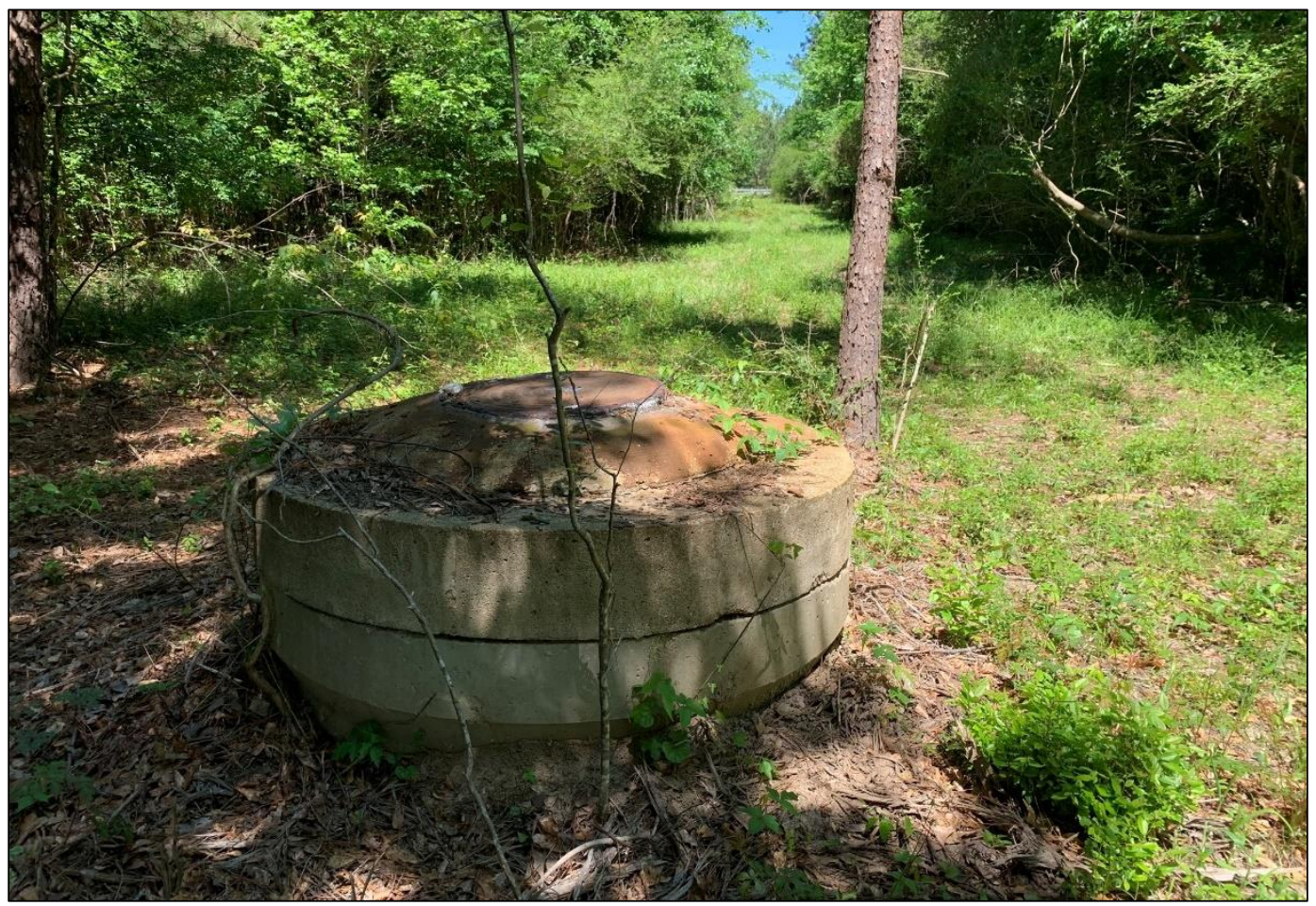

Figure 8. View of ROW South of Foster Drive (Facing Northeast)

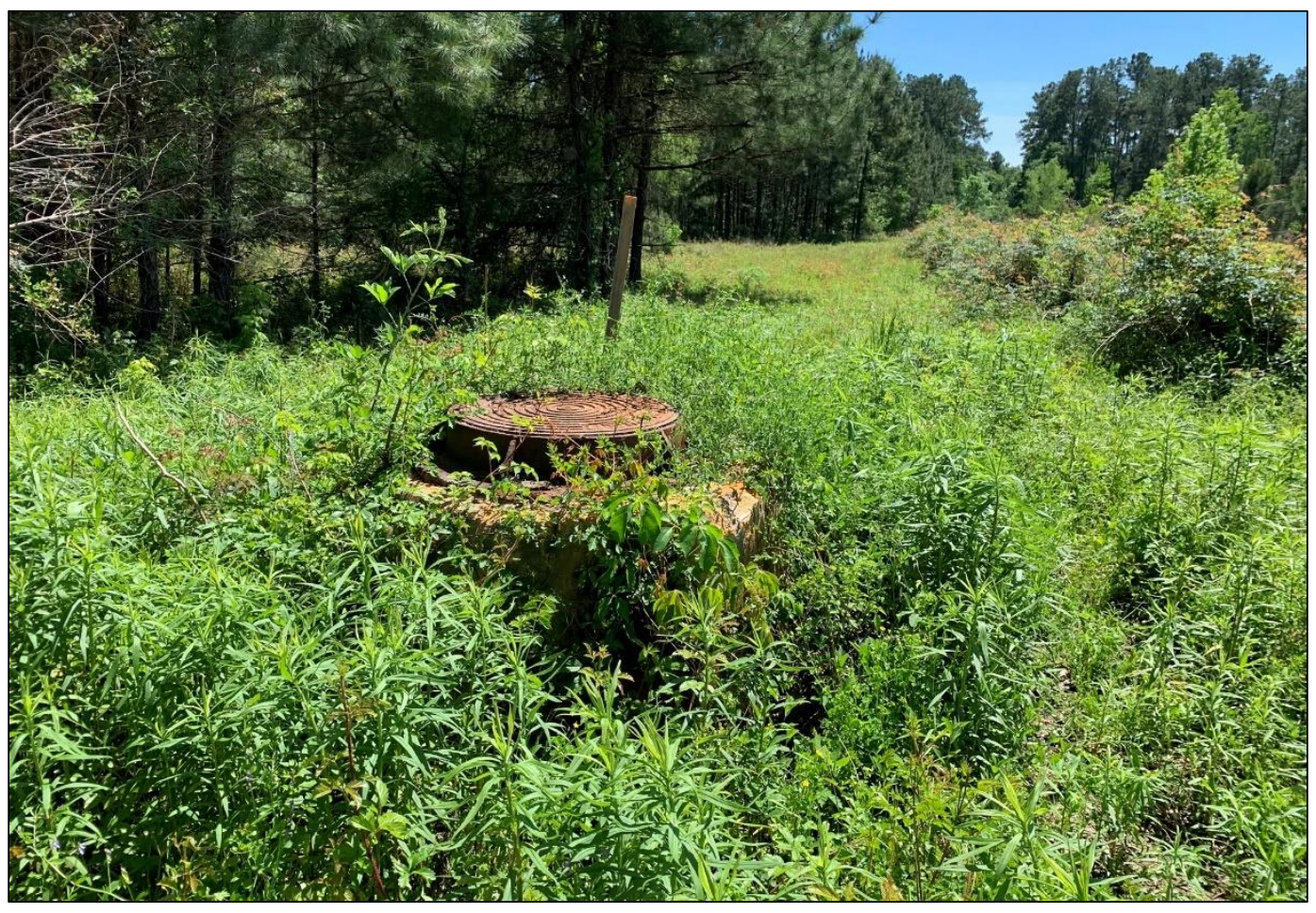

Figure 9. View of ROW North of Foster Drive (Facing North) 


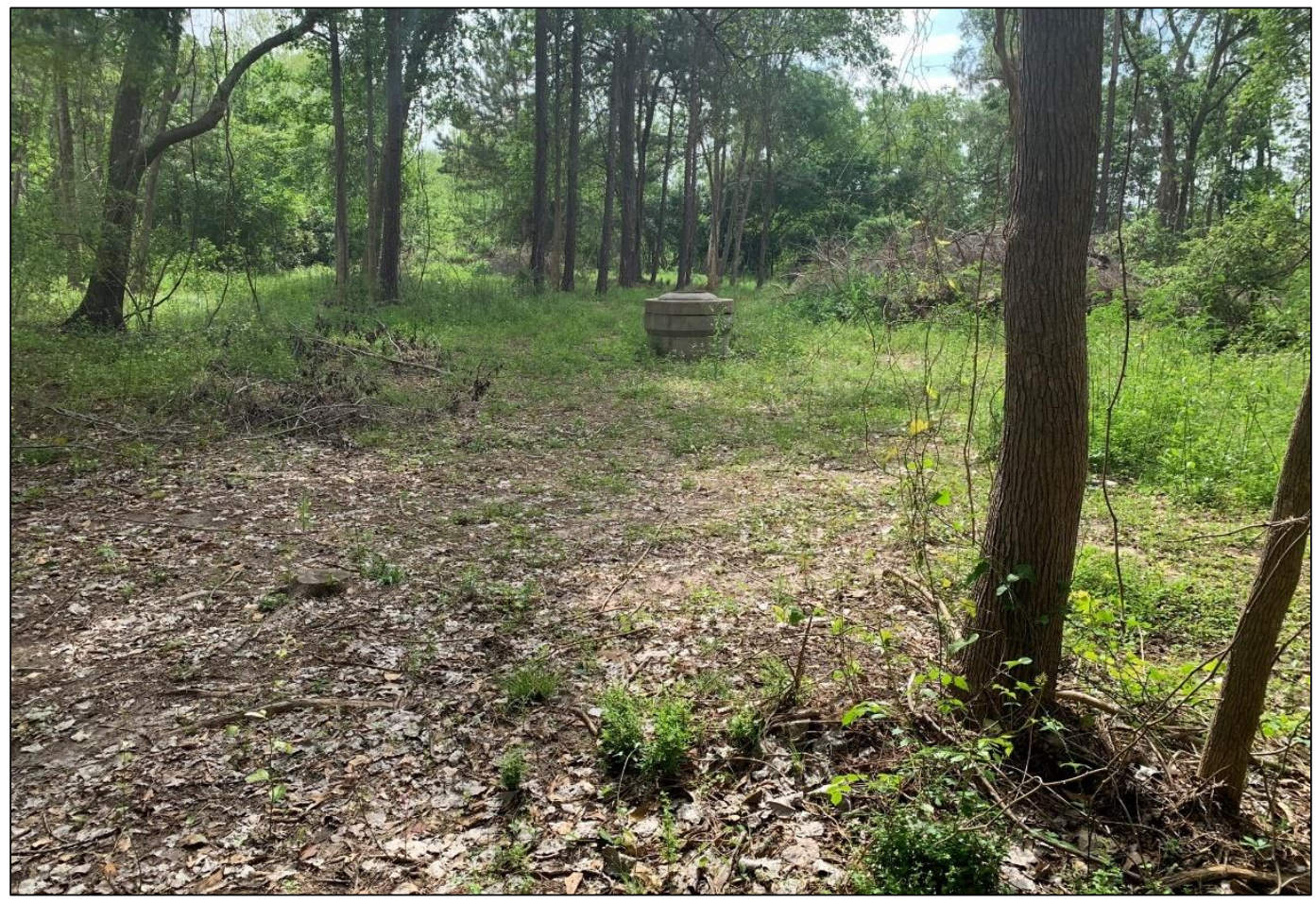

Figure 10. View of ROW South of Silverdale Drive (Facing South-Southeast)

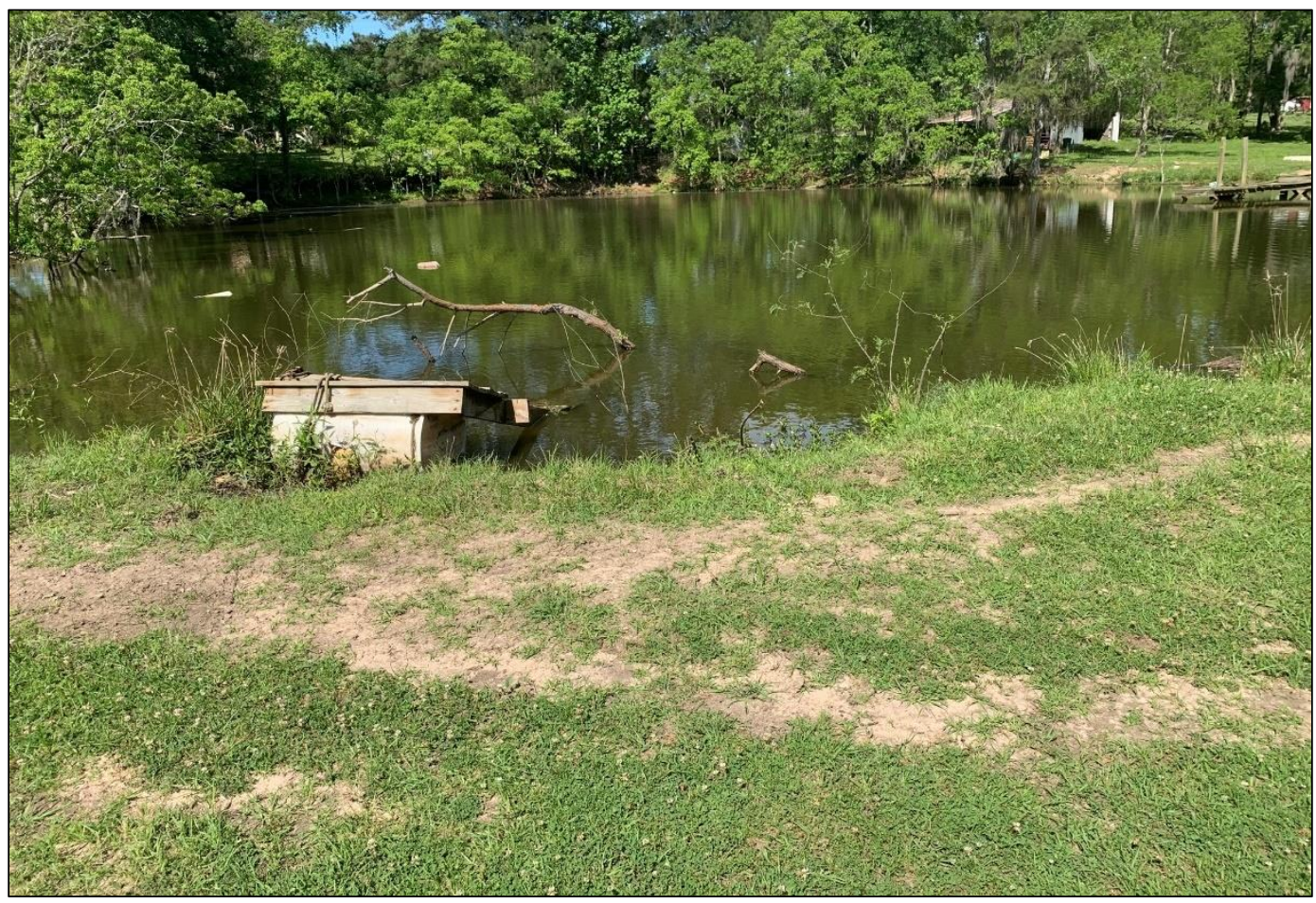

Figure 11. View of Stock Pond Near Southern End of ROW near ST CK02 (Facing West) 
Intensive Cultural Resources Survey of the Proposed City of Conroe's

Stewarts Creek Wastewater System Improvements Project, Conroe, Montgomery County, Texas

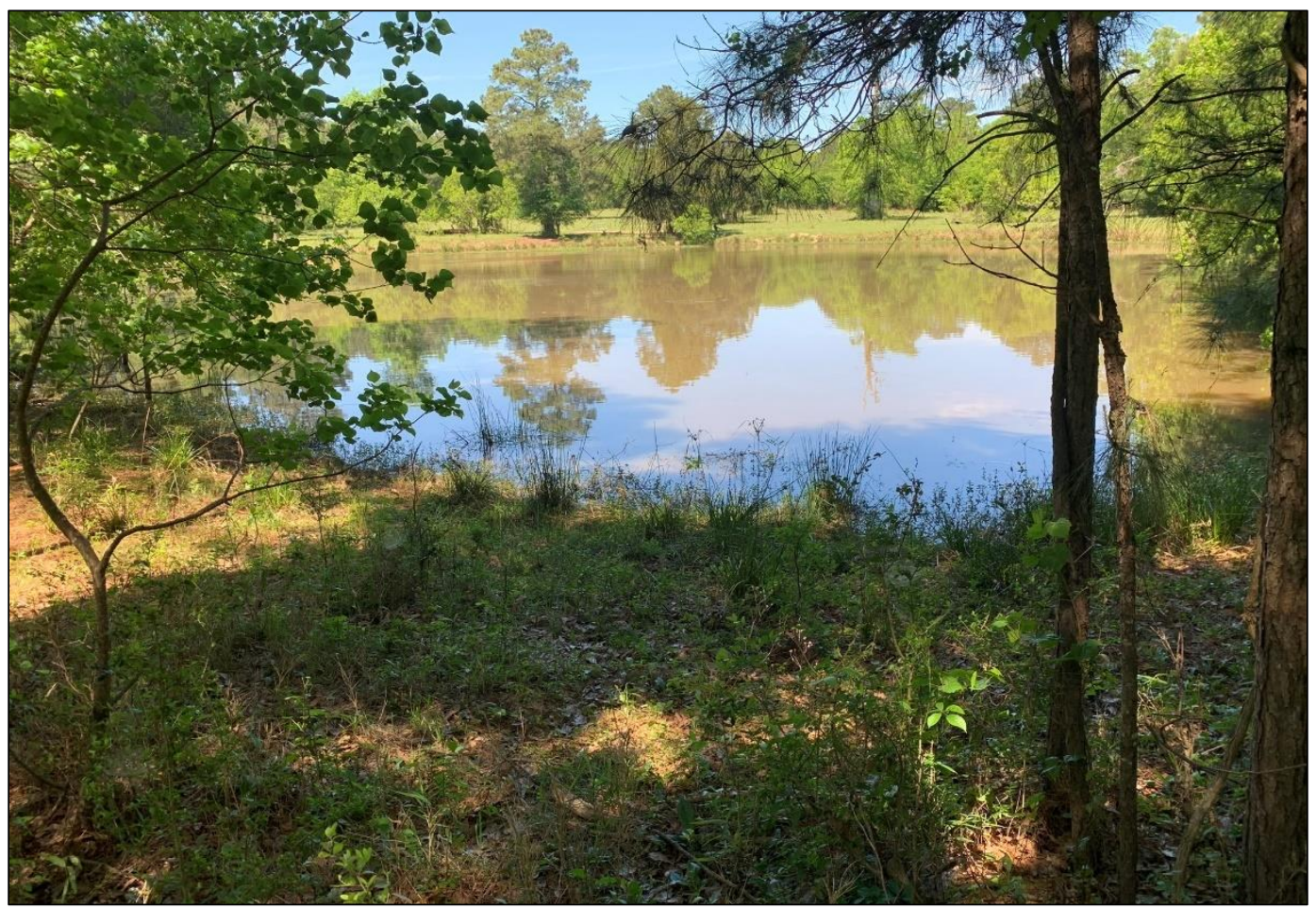

Figure 12. View of Stock Pond Near ROW South of Foster Drive (Facing Northwest)

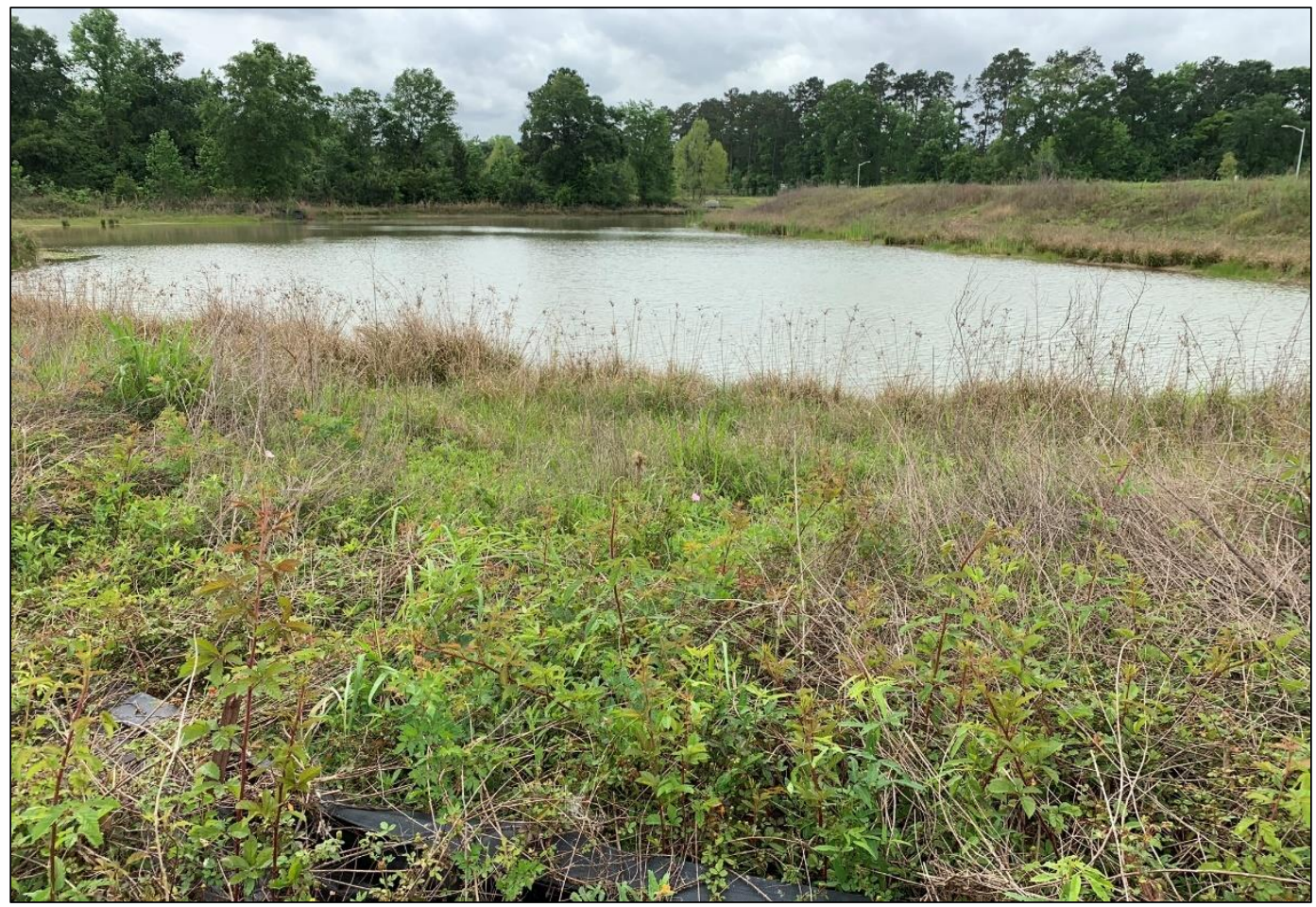

Figure 13. View of Stock Pond North of Foster Drive (Facing South) 


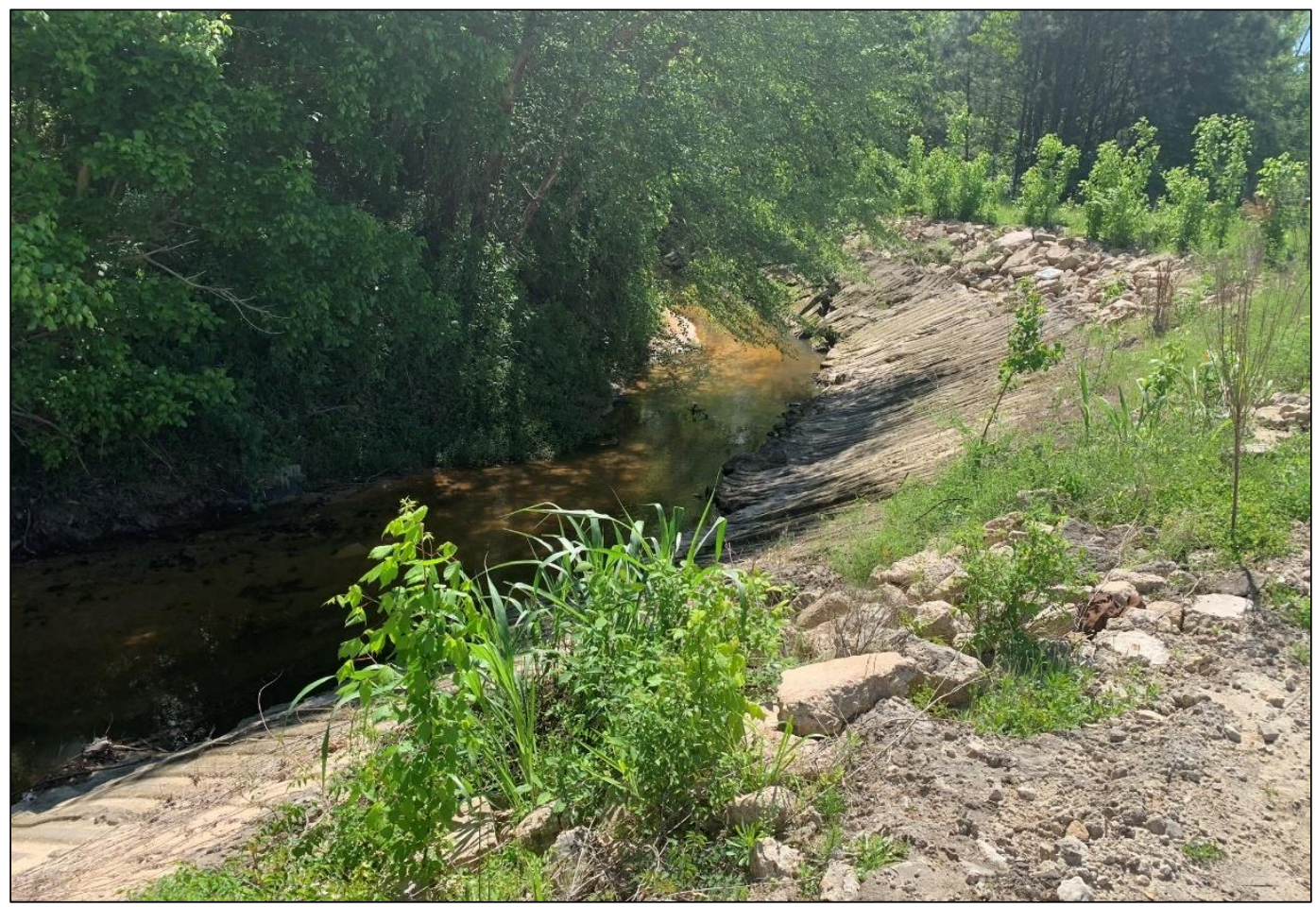

Figure 14. View of Concrete-Lined Banks of Stewarts Creek near Southern End of ROW (Facing Southeast)

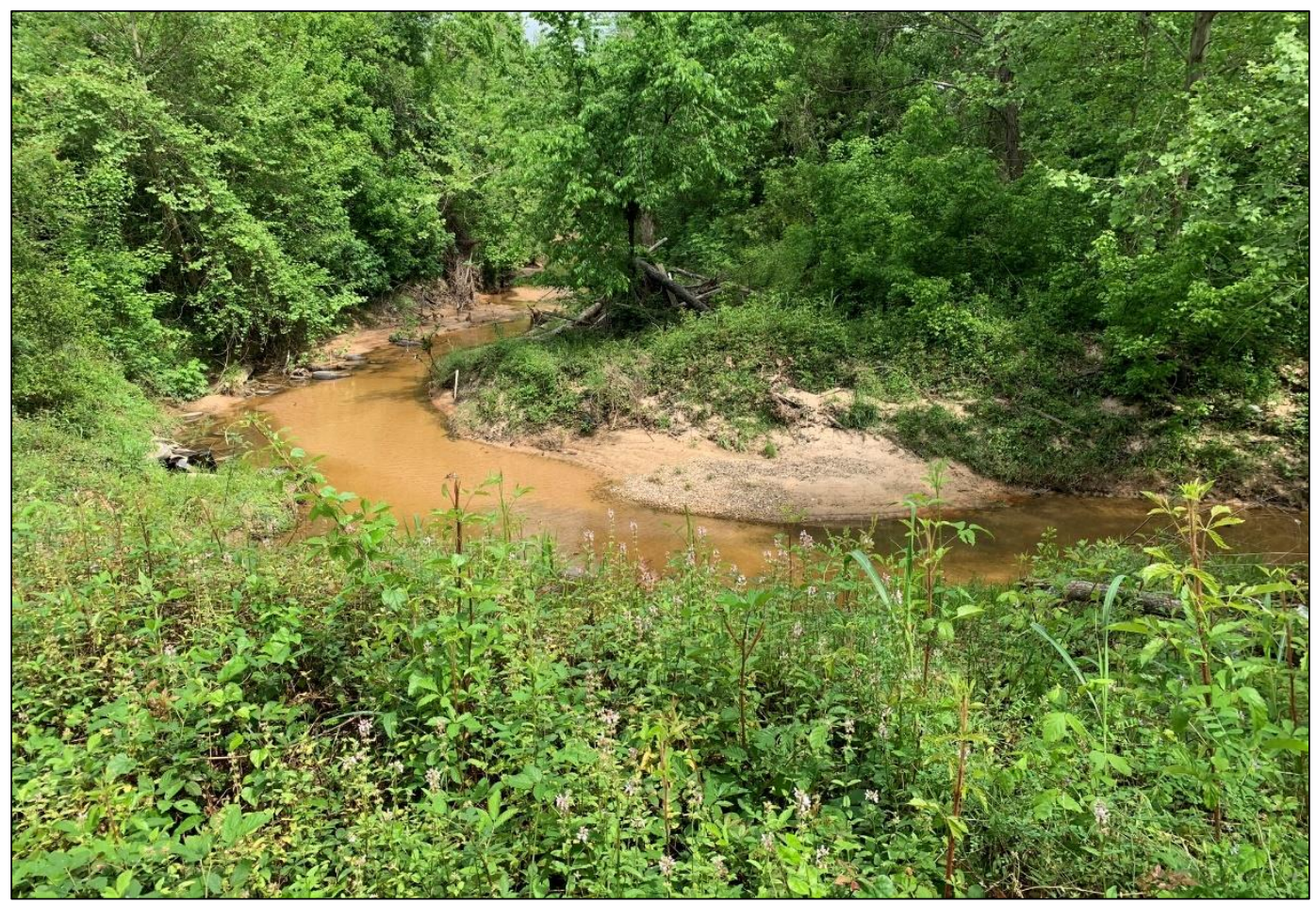

Figure 15. Stewarts Creek between Silverdale Drive and Foster Drive (Facing East) 
Intensive Cultural Resources Survey of the Proposed City of Conroe's

Stewarts Creek Wastewater System Improvements Project, Conroe, Montgomery County, Texas

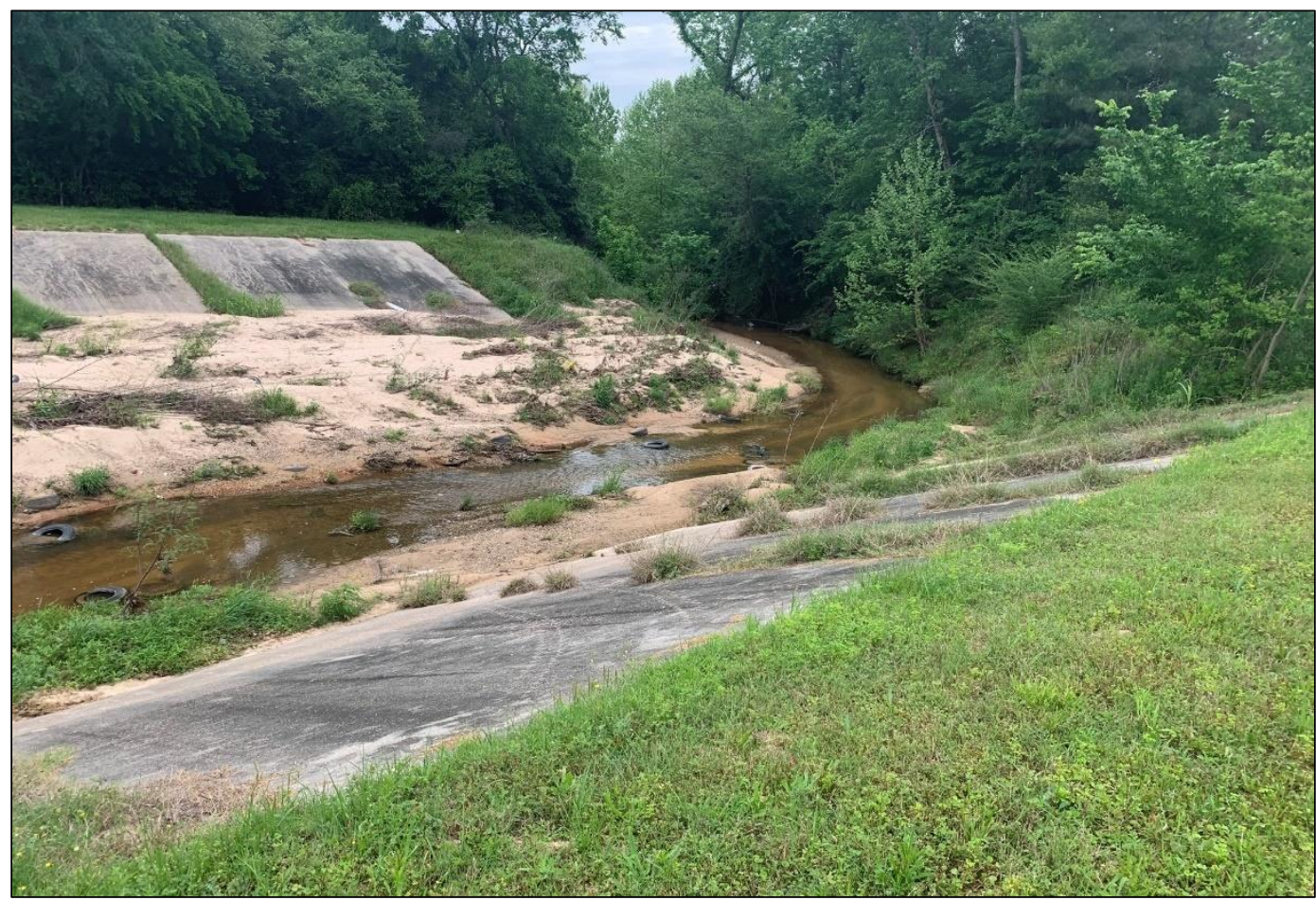

Figure 16. View of Stewarts Creek South of Silverdale Drive Bridge (Facing Southeast)

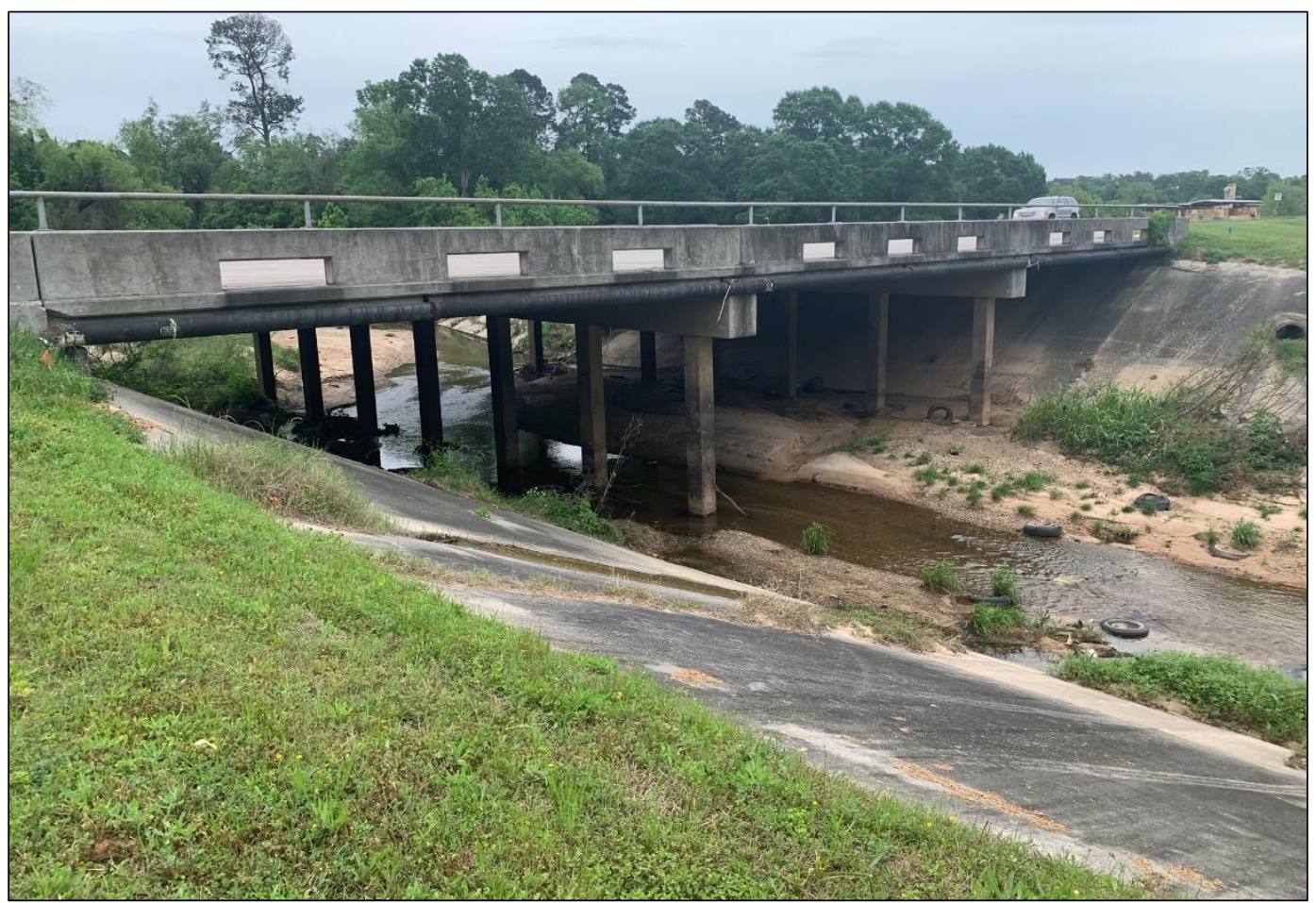

Figure 17. View of Stewarts Creek at Silverdale Drive Bridge (Facing Northeast) 


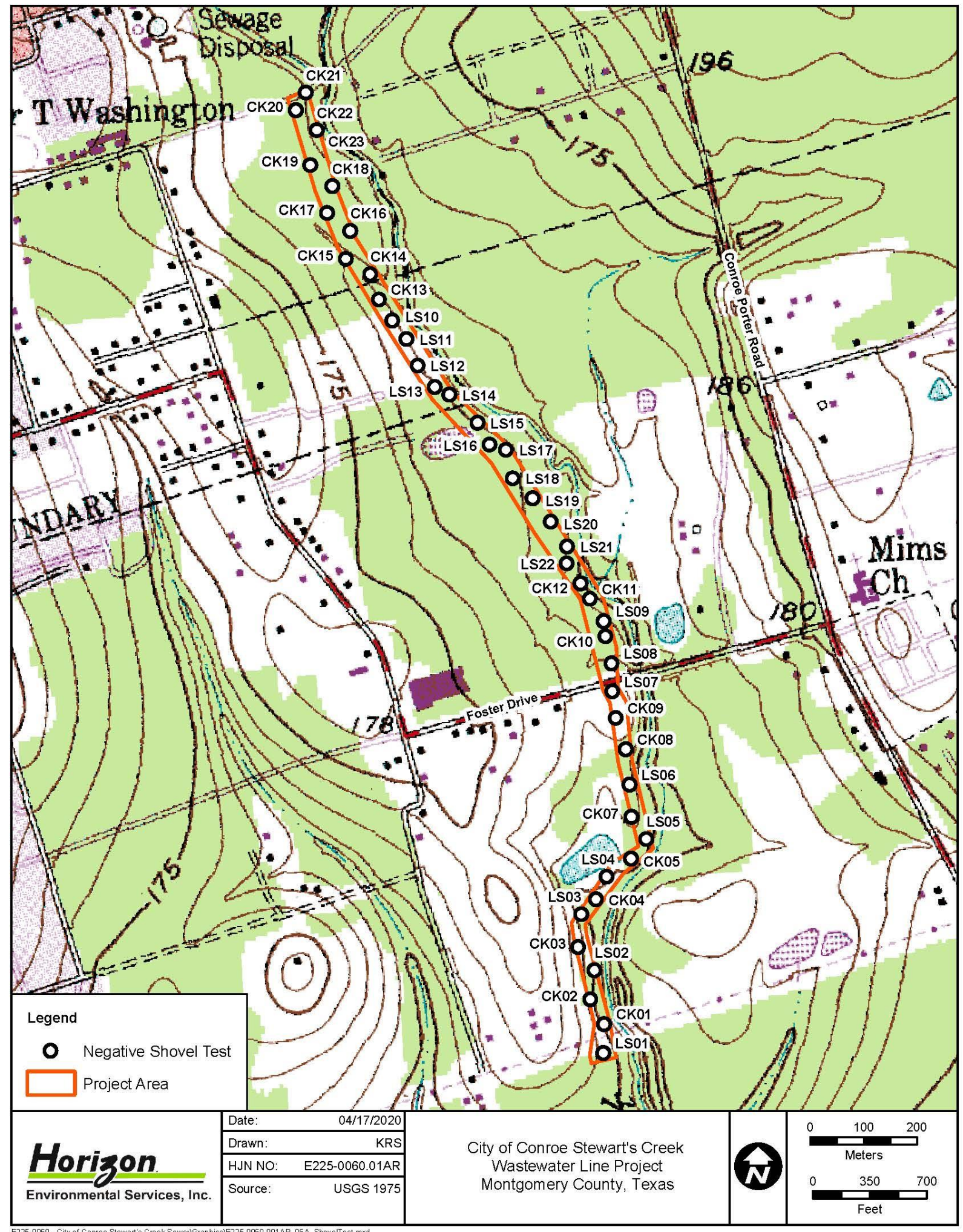

Figure 18. Locations of Shovel Tests Excavated within Project Area 
Intensive Cultural Resources Survey of the Proposed City of Conroe's

Stewarts Creek Wastewater System Improvements Project, Conroe, Montgomery County, Texas

Collector for ArcGIS data collection software based on the North American Datum of 1983 (NAD 83). Shovel testing typically revealed mixed brown to yellowish-brown sandy loam and sandy sediments with rare hematitic sandstone and oyster shell fragment inclusions. Mottling and mixing was observed in virtually every shovel test, suggesting that sediments within the survey corridor had been disturbed during the original construction of the sewer line. Given the extent of disturbance observed within the shovel tests excavated during the survey, it is Horizon's opinion that sediments within the proposed disturbance zone associated with rehabilitation and replacement of the existing sewer line have been disturbed to the depth of the existing pipeline and have minimal potential to contain any intact archeological deposits. Furthermore, a prior survey was conducted for the City of Conroe in 2001 that included mechanical deep testing, though this survey did not result in the documentation of any cultural resources along this segment of Stewarts Creek (Mason and Garcia-Herreros 2002). As such, it is Horizon's opinion that the shovel testing was capable of evaluating the potential of the project area to contain prehistoric and historic-age cultural resources with the potential to meet the criteria of significance for inclusion in the NRHP and for designation as SALs. Specific shovel testing data are presented in Appendix A.

During the survey, field notes were maintained on terrain, vegetation, soils, landforms, survey methods, and shovel test results. Digital photographs were taken, and a photographic log was maintained. Horizon employed a non-collection policy for cultural resources. Diagnostic artifacts (e.g., projectile points, ceramics, historic materials with maker's marks) and nondiagnostic artifacts (e.g., lithic debitage, burned rock, historic glass, and metal scrap) were to be described, sketched, and/or photo-documented in the field and replaced in the same location in which they were found. As no cultural resources were observed, no cultural resources were collected and the collection policy was not enacted. Following completion of the project, records will be prepared for permanent curation at the Texas Archeological Research Laboratory (TARL).

The survey methods employed during the survey represented a "reasonable and good-faith effort" to locate significant archeological sites within the project area as defined in 36 CFR 800.3. 



\subsection{RESULTS OF INVESTIGATIONS}

On April 1 to 2, 2020, Horizon archeologists Colene Knaub and Elizabeth Sefton, under the overall direction of Jeffrey D. Owens, Principal Investigator, performed an intensive cultural resources survey of the project area to locate any cultural resources that potentially would be impacted by the proposed undertaking. The survey was performed under Texas Antiquities Permit No. 9336. Horizon's archeologists traversed the archeological survey area on foot and thoroughly inspected the modern ground surface for aboriginal and historic-age cultural resources. The survey area consisted of an existing gravity sewer ROW running along the western terraces of Stewarts Creek. Most of the sewer line ROW consisted of broad, cleared areas characterized by short, manicured grasses, though some segments of the ROW appear not to have been regularly maintained and had become heavily overgrown with tall grasses, weeds, and wildflowers. Large concrete manholes providing access to the existing sewer line are spaced at regular intervals along this utility corridor. The ROW crosses Silverdale Drive, Foster Drive, and an electrical transmission line, and four large stock ponds are present adjacent to the ROW that involved extensive earth-moving activities within the project corridor. The streambanks along most of the central and southern portions of Stewarts Creek have been contoured and covered in cement lining, though isolated sections of the creek have not been modified. Prior disturbances within the existing sewer line corridor associated with construction and maintenance of the existing sewer line, stock ponds, intersecting roadways, and the transmission line have been extensive. Overall, ground surface visibility was generally poor $(<30 \%)$ due to dense vegetative ground cover.

In addition to pedestrian walkover, the TSMASS require a minimum of 10 shovel tests per 1.0 kilometer (16 shovel tests per 1.0 mile) for linear projects per 30.5 -meter (100.0-foot) width of ROW, or fraction thereof. As such, a minimum of 42 shovel tests would be required within the 2.1-kilometer- (1.3-mile-) long by 39.6-meter- (130.0-foot-) wide project area. Horizon excavated 44 shovel tests during the survey, thereby exceeding the TSMASS requirements for a project area of this size (Figure 18). Shovel tests were staggered along either side of the existing sewer line as evidenced by the locations of manholes in an effort to test sediments that potentially had been less disturbed by the original construction of the sewer line.

Shovel testing typically revealed mixed brown to yellowish-brown sandy loam and sandy sediments with rare hematitic sandstone and oyster shell fragment inclusions. Mottling and mixing was observed in virtually every shovel test, suggesting that sediments within the survey corridor had been disturbed during the original construction of the sewer line. Given the extent of 
disturbance observed within the shovel tests excavated during the survey, it is Horizon's opinion that sediments within the proposed disturbance zone associated with rehabilitation and replacement of the existing sewer line have been disturbed to the depth of the existing pipeline and have minimal potential to contain any intact archeological deposits. Furthermore, a prior survey was conducted for the City of Conroe in 2001 that included mechanical deep testing, though this survey did not result in the documentation of any cultural resources along this segment of Stewarts Creek (Mason and Garcia-Herreros 2002). As such, it is Horizon's opinion that the shovel testing was capable of evaluating the potential of the project area to contain prehistoric and historic-age cultural resources with the potential to meet the criteria of significance for inclusion in the NRHP and for designation as SALs.

No cultural resources, prehistoric or historic-age, were observed on the modern ground surface or within any of the shovel tests excavated within the project area. As no cultural resources were observed during the survey, no cultural resources were collected. Following completion of the project, all project records will be prepared for permanent curation at TARL. 


\subsection{SUMMARY AND RECOMMENDATIONS}

\subsection{Conceptual Framework}

The archeological investigations documented in this report were undertaken with three primary management goals in mind:

- Locate all historic and prehistoric archeological resources that occur within the designated survey area.

- Evaluate the significance of these resources regarding their potential for inclusion in the NRHP and for designation as SALs.

- Formulate recommendations for the treatment of these resources based on their NRHP and SAL evaluations.

At the survey level of investigation, the principal research objective is to inventory the cultural resources within the project area and to make preliminary determinations of whether or not the resources meet one or more of the pre-defined eligibility criteria set forth in the state and/or federal codes, as appropriate. Usually, management decisions regarding archeological properties are a function of the potential importance of the sites in addressing defined research needs, though historic-age sites may also be evaluated in terms of their association with important historic events and/or personages. Under the NHPA and the Antiquities Code of Texas, archeological resources are evaluated according to criteria established to determine the significance of archeological resources for inclusion in the NRHP and for designation as SALs, respectively.

Analyses of the limited data obtained at the survey level are rarely sufficient to contribute in a meaningful manner to defined research issues. The objective is rather to determine which archeological sites could be most profitably investigated further in pursuance of regional, methodological, or theoretical research questions. Therefore, adequate information on site function, context, and chronological placement from archeological and, if appropriate, historical perspectives is essential for archeological evaluations. Because research questions vary as a function of geography and temporal period, determination of the site context and chronological placement of cultural properties is a particularly important objective during the inventory process. 
Chapter 7.0: Summary and Recommendations

\subsection{Eligibility CRiteria for InCLUSion in the National Register of Historic Places}

Determinations of eligibility for inclusion in the NRHP are based on the criteria presented in 36 CFR $\S 60.4(a-d)$. The four criteria of eligibility are applied following the identification of relevant historical themes and related research questions:

The quality of significance in American history, architecture, archeology, and culture is present in districts, sites, buildings, structures, and objects that possess integrity of location, design, setting, materials, workmanship, feeling, and association, and:

a. [T]hat are associated with events that have made a significant contribution to the broad patterns of our history; or,

b. [T]hat are associated with the lives of persons significant in our past; or,

c. [T]hat embody the distinctive characteristics of a type, period, or method of construction, or that represent a significant and distinguishable entity whose components may lack individual distinction; or,

d. [T]hat have yielded, or may be likely to yield, information important in prehistory or history.

The first step in the evaluation process is to define the significance of the property by identifying the particular aspect of history or prehistory to be addressed and the reasons why information on that topic is important. The second step is to define the kinds of evidence or the data requirements that the property must exhibit to provide significant information. These data requirements in turn indicate the kind of integrity that the site must possess to be significant. This concept of integrity relates both to the contextual integrity of such entities as structures, districts, or archeological deposits and to the applicability of the potential database to pertinent research questions. Without such integrity, the significance of a resource is very limited.

For an archeological resource to be eligible for inclusion in the NRHP, it must meet legal standards of eligibility that are determined by three requirements: (1) properties must possess significance, (2) the significance must satisfy at least one of the four criteria for eligibility listed above, and (3) significance should be derived from an understanding of historic context. As discussed here, historic context refers to the organization of information concerning prehistory and history according to various periods of development in various times and at various places. Thus, the significance of a property can best be understood through knowledge of historic development and the relationship of the resource to other, similar properties within a particular period of development. Most prehistoric sites are usually only eligible for inclusion in the NRHP under Criterion $\mathrm{D}$, which considers their potential to contribute data important to an understanding of prehistory. All four criteria employed for determining NRHP eligibility potentially can be brought to bear for historic sites. 
Intensive Cultural Resources Survey of the Proposed City of Conroe's

Stewarts Creek Wastewater System Improvements Project, Conroe, Montgomery County, Texas

\subsection{EligibiLity Criteria for Listing as a State Antiquities Landmark}

The criteria for determining the eligibility of a prehistoric or historic cultural property for designation as an SAL are presented in Chapter 191, Subchapter D, Section 191.092 of the Antiquities Code of Texas, which states that SALs include:

Sites, objects, buildings, artifacts, implements, and locations of historical, archeological, scientific, or educational interest including those pertaining to prehistoric and historical American Indians or aboriginal campsites, dwellings, and habitation sites, their artifacts and implements of culture, as well as archeological sites of every character that are located in, on, or under the surface of any land belonging to the State of Texas or to any county, city, or political subdivision of the state are state antiquities landmarks and are eligible for designation.

For the purposes of assessing the eligibility of a historic property for designation as an SAL, a historic site, structure, or building has historical interest if the site, structure, or building:

1. [W]as the site of an event that has significance in the history of the United States or the State of Texas;

2. [W]as significantly associated with the life of a famous person;

3. [W]as significantly associated with an event that symbolizes an important principle or ideal;

4. [R]epresents a distinctive architectural type and has value as an example of a period, style, or construction technique; or,

5. [l]s important as part of the heritage of a religious organization, ethic group, or local society.

The Antiquities Code of Texas establishes the THC as the legal custodian of all cultural resources, historic and prehistoric, within the public domain of the State of Texas. Under Part II of Title 13 of the Texas Administrative Code (13 TAC 26), the THC may designate a historic building, structure, cultural landscape, or non-archeological site, object, or district as an SAL if it meets at least one of following criteria:

A. [T]he property is associated with events that have made a significant contribution to the broad patterns of our history, including importance to a particular cultural or ethnic group;

B. [T]he property is associated with the lives of persons significant in our past;

C. [T]he property embodies the distinctive characteristics of a type, period, or method of construction, represents the work of a master, possesses high artistic values, or represents a significant and distinguishable entity whose components may lack individual distinction;

D. [T]he property has yielded, or may be likely to yield, information important in Texas culture or history. 
Furthermore, the THC may designate an archeological site as an SAL if the site meets one or more of the following criteria:

1. [T] he site has the potential to contribute to a better understanding of the prehistory and/or history of Texas by the addition of new and important information;

2. [T]he site's archeological deposits and the artifacts within the site are preserved and intact, thereby supporting the research potential or preservation interests of the site;

3. [T] he site possesses unique or rare attributes concerning Texas prehistory and/or history;

4. [T]he study of the site offers the opportunity to test theories and methods of preservation, thereby contributing to new scientific knowledge; or,

5. [T]he high likelihood that vandalism and relic collecting has occurred or could occur, and official landmark designation is needed to ensure maximum legal protection, or alternatively further investigations are needed to mitigate the effects of vandalism and relic collecting when the site cannot be protected.

\subsection{SUMMARY OF INVENTORY RESULTS}

On April 1 to 2, 2020, Horizon archeologists Colene Knaub and Elizabeth Sefton, under the overall direction of Jeffrey D. Owens, Principal Investigator, performed an intensive cultural resources survey of the project area to locate any cultural resources that potentially would be impacted by the proposed undertaking. The survey was performed under Texas Antiquities Permit No. 9336. Horizon's archeologists traversed the archeological survey area on foot and thoroughly inspected the modern ground surface for aboriginal and historic-age cultural resources. The survey area consisted of an existing gravity sewer ROW running along the western terraces of Stewarts Creek. Most of the sewer line ROW consisted of broad, cleared areas characterized by short, manicured grasses, though some segments of the ROW appear not to have been regularly maintained and had become heavily overgrown with tall grasses, weeds, and wildflowers. Large concrete manholes providing access to the existing sewer line are spaced at regular intervals along this utility corridor. The ROW crosses Silverdale Drive, Foster Drive, and an electrical transmission line, and four large stock ponds are present adjacent to the ROW that involved extensive earth-moving activities within the project corridor. Prior disturbances within the existing sewer line corridor associated with construction and maintenance of the existing sewer line, stock ponds, intersecting roadways, and the transmission line have been extensive. Overall, ground surface visibility was generally poor $(<30 \%)$ due to dense vegetative ground cover.

In addition to pedestrian walkover, the TSMASS require a minimum of 10 shovel tests per 1.0 kilometer (16 shovel tests per 1.0 mile) for linear projects per 30.5-meter (100.0-foot) width of ROW, or fraction thereof. As such, a minimum of 42 shovel tests would be required within the 2.1-kilometer- (1.3-mile-) long by 39.6-meter- (130.0-foot-) wide project area. Horizon excavated 44 shovel tests during the survey, thereby exceeding the TSMASS requirements for a project area of this size. Shovel tests were staggered along either side of the existing sewer line as 
Intensive Cultural Resources Survey of the Proposed City of Conroe's

Stewarts Creek Wastewater System Improvements Project, Conroe, Montgomery County, Texas

evidenced by the locations of manholes in an effort to test sediments that potentially had been less disturbed by the original construction of the sewer line.

Shovel testing typically revealed mixed brown to yellowish-brown sandy loam and sandy sediments with rare hematitic sandstone and oyster shell fragment inclusions. Mottling and mixing was observed in virtually every shovel test, suggesting that sediments within the survey corridor had been disturbed during the original construction of the sewer line. Given the extent of disturbance observed within the shovel tests excavated during the survey, it is Horizon's opinion that sediments within the proposed disturbance zone associated with rehabilitation and replacement of the existing sewer line have been disturbed to the depth of the existing pipeline and have minimal potential to contain any intact archeological deposits. Furthermore, a prior survey was conducted for the City of Conroe in 2001 that included mechanical deep testing, though this survey did not result in the documentation of any cultural resources along this segment of Stewarts Creek. As such, it is Horizon's opinion that the shovel testing was capable of evaluating the potential of the project area to contain prehistoric and historic-age cultural resources with the potential to meet the criteria of significance for inclusion in the NRHP and for designation as SALS.

No cultural resources, prehistoric or historic-age, were observed on the modern ground surface or within any of the shovel tests excavated within the project area. As no cultural resources were observed during the survey, no cultural resources were collected. Following completion of the project, all project records will be prepared for permanent curation at TARL.

\subsection{MANAGement ReCOMmendations}

Based on the results of the survey-level investigations documented in this report, no potentially significant cultural resources would be affected by the proposed undertaking. In accordance with 36 CFR 800.4, Horizon has made a reasonable and good-faith effort to identify historic properties within the project area. No cultural resources were identified within the project area that meet the criteria for designation as SALs according to 13 TAC 26 or for inclusion in the NRHP under 36 CFR 60.4. Horizon recommends a finding of "no historic properties affected," and no further archeological work is recommended in connection with the proposed undertaking. However, human burials, both prehistoric and historic, are protected under the Texas Health and Safety Code. In the event that any human remains or burial objects are inadvertently discovered at any point during construction, use, or ongoing maintenance in the project area, even in previously surveyed areas, all work should cease immediately in the vicinity of the inadvertent discovery, and the THC should be notified immediately. 



\subsection{REFERENCES CITED}

Abbott, J.T.

2001 Houston Area Geoarcheology-A Framework for Archeological Investigation, Interpretation, and Cultural Resource Management in the Houston Highway District. Archeological Studies Program, Report No. 27, Environmental Affairs Division, Texas Department of Transportation, Austin.

Adovasio, J.M., J. Donahue, and R. Stuckenrath

1990 The Meadowcroft Rockshelter Chronology 1975-1990. American Antiquity 55:348354.

Aten, L.E.

1983 Indians of the Upper Texas Coast. Academic Press, New York.

1984 Woodland Cultures of the Texas Coast. In Perspectives on Gulf Coast Prehistory, pp. 72-93. Ripley P. Bullen Monographs in Anthropology and History, No. 5, The Florida State Museum, Gainesville.

Blair, W.F.

1950 The Biotic Provinces of Texas. Texas Journal of Science 2:93-117.

Bryant, V.M., Jr., and R.G. Holloway

1985 A Late-Quaternary Paleoenvironmental Record of Texas: An Overview of the Pollen Evidence. In Pollen Records of Late-Quaternary North American Sediments, edited by V.M. Bryant, Jr., and R.G. Holloway, pp. 39-70. American Association of Stratigraphic Palynologists Foundation, Dallas, Texas.

Collins, M.B.

1995 Forty Years of Archeology in Central Texas. Bulletin of the Texas Archeological Society 66:361-400.

Dillehay, T.D.

1989 Monte Verde: A Late Pleistocene Settlement in Chile-Paleoenvironment and Site Context, Vol. 1. Smithsonian Institution Press: Washington, D.C.

1997 Monte Verde: A Late Pleistocene Settlement in Chile-The Archaeological Context, Vol. 2. Smithsonian Institution Press: Washington, D.C. 


\section{Dincauze, D.F.}

1984 An Archaeo-Logical Evaluation of the Case for Pre-Clovis Occupations. Advances in World Archaeology 3:275-323. Academic Press, New York.

Ellis, L.W.

2013 Woodland Ceramics in East Texas and a Case Study of Mill Creek Culture Ceramics. Bulletin of the Texas Archeological Society 84:137-180.

Ensor, H.B., and D.L. Carlson (editors)

1991 Alabonson Road: Early Ceramic Period Adaptations to the Inland Coastal Prairie Zone, Harris County, Southeast Texas. Reports of Investigations, No. 8, Archeological Research Laboratory, Texas A\&M University, College Station.

Environmental Systems Research Institute (Esri)

2017 Digital orthographic photography sourced by Esri for ArcGIS Online. <arcgis.com>. Accessed March 5, 2017.

Etienne-Gray, T.

2010 Goodrich Jones State Forest. The Handbook of Texas Online. <https://tshaonline.org /handbook/online/articles/gkwsk>. Uploaded June 15, 2010. Accessed July 2, 2019.

Grandy, W.H.

1952 A History of Montgomery County, Texas. Unpublished Master's thesis, University of Houston, Texas.

Hall, G.D.

1981 Allens Creek: A Study in the Cultural Prehistory of the Lower Brazos River Valley, Texas. Research Report No. 61, Texas Archeological Survey, The University of Texas at Austin.

Haynes, C.V., Jr., D.J. Donahue, A.J. T. Hull, and T.H. Zabel

1984 Application of Accelerator Dating to Fluted Point Paleoindian Sites. Archaeology of Eastern North America 12:184-191.

Henson, M.S.

2010 Harris County. The Handbook of Texas Online. <https://tshaonline.org/handbook/ online/articles/hch07>. Uploaded June 15, 2010. Accessed June 27, 2019.

Kelly, R.L., and L.C. Todd

1988 Coming into the Country: Early Paleo-Indian Hunting and Mobility. American Antiquity 53:231-244.

Keller, J.E., and F.A. Weir

1979 The Strawberry Hill Site. Publications in Archeology, Report No. 13. Texas State Department of Highways, Austin.

Ladd, K.

2010 El Orcoquisac. The Handbook of Texas Online. <https://tshaonline.org/handbook/ online/articles/hve49>. Uploaded June 15, 2010. Accessed June 27, 2019. 
Intensive Cultural Resources Survey of the Proposed City of Conroe's

Stewarts Creek Wastewater System Improvements Project, Conroe, Montgomery County, Texas

Larkin, T. J., and G. W. Bomar

1983 Climatic Atlas of Texas. Publication LP-192. Texas Department of Water Resources, Austin.

Long, C.

2010a Montgomery County. The Handbook of Texas Online. <https://tshaonline.org/hand book/online/articles/hcm17>. Uploaded June 15, 2010. Accessed July 1, 2019.

2010b Sam Houston National Forest. The Handbook of Texas Online. <https://tshaonline. org/handbook/online/articles/gks02>. Uploaded June 15, 2010. Accessed July 2, 2019

Lynch, T.F.

1990 Glacial-Age Man in South America?: A Critical Review. American Antiquity 55(1):1236.

Mason, J.B., and J. Garcia-Herreros

2002 Phase I Survey and Deep Testing of Stewarts Creek Channel for the City of Conroe, Montgomery County, Texas. BHE Environmental, Inc. Houston, Texas.

Meltzer, D.J.

1989 Why Don't We Know When the First People Came to America? American Antiquity 54(3):471-490.

Meltzer, D.J., D.K. Grayson, G. Ardila, A.W. Barker, D.F. Dincauze, C.V. Haynes, F. Mena, L. Nuñez, and D.J. Stanford

1997 On the Pleistocene Antiquity of Monte Verde, Southern Chile. American Antiquity 62(4):659-663.

Montgomery, R.N.

2010 Montgomery, Andrew Jackson. The Handbook of Texas Online. <https://tshaonline. org/handbook/online/articles/fmo90>. Uploaded June 15, 2010. Accessed July 1, 2019

Natural Resources Conservation Service (NRCS)

2019 Web Soil Survey. <http://websoilsurvey.nrcs.usda.gov/app/WebSoilSurvey.aspx>. Accessed September 16, 2019.

2020 Web Soil Survey. <http://websoilsurvey.nrcs.usda.gov/app/WebSoilSurvey.aspx>. Accessed April 16, 2020.

National Environmental Title Research (NETR)

2020 Historic Aerials by NETR Online. <http://www.historicaerials.com>. Accessed February 12, 2020.

Newcomb, W.W. Jr.

1961 The Indians of Texas: From Prehistoric to Modern Times. University of Texas Press: Austin. 


\section{Open Street Map (OSM)}

2020 OpenStreetMap. <http://www.openstreetmap .org>. Available under the Open Database License: <www.opendatacommons.org/licenses/odbl>. Accessed February 12, 2020.

Patterson, L. W.

1980 The Owen Site, 41HR315: A Long Occupation Sequence in Harris County, Texas. Houston Archeological Society, Report No. 3.

1995 The Archeology of Southeast Texas. Bulletin of the Texas Archeological Society 66:239-264

Patterson, L.W., J.D. Lockwood, R.L. Gregg, and S.M. Kindall

1993 Prehistoric Site 41HR354, 730, 731, 732, Harris County, Texas. Houston Archeological Society Journal 104:25-30.

Pertulla, T.K., M.R. Miller, R.A. Ricklis, D.J. Prikryl, and C.Lintz

1995 Prehistoric and Historic Aboriginal Ceramics in Texas. Bulletin of the Texas Archeological Society 66:175-235.

Prewitt, E.

1981 Cultural Chronology in Central Texas. Bulletin of the Texas Archeological Society 52:65-90.

Ricklis, R.A.

1994 Aboriginal Life and Culture on the Upper Texas Coast: Archaeology at the Mitchell Ridge Site, 41GB66, Galveston Island. Coastal Archaeological Research, Inc., Corpus Christi, Texas.

1995 Prehistoric Occupation of the Central and Lower Texas Coast: A Regional Overview. Bulletin of the Texas Archeological Society 66:265-330

2003 The Archeology of the Native American Occupation of Southeast Texas. In The Prehistory of Texas, edited by Timothy K. Perttula. Texas A\&M University Press: College Station.

2013 The Rockport Ware Pottery of the Central Texas Coast: Form, Technology, Style, and Ethnic Affiliation. In Bulletin of the Texas Archeological Society 84:85-111.

Shelby, C.A., M.K. McGowen, S. Aranow, W.L. Fisher, L.F. Brown, Jr., J.H. McGowen, C.G. Groat, and V.E. Barnes

1968 Geologic Atlas of Texas-Beaumont Sheet. Bureau of Economic Geology, The University of Texas at Austin (Revised 1992).

Story, D.A.

1990 Cultural History of the Native Americans. In The Archeology and Bioarcheology of the Gulf Coastal Plain, by D.A. Story, J.A. Guy, B.A. Burnett, M.D. Freeman, J.C. Rose, D.G. Steele, B.W. Olive, and K.J. Reinhard, pp. 163-366. Two Volumes. Research Series No. 38, Arkansas Archeological Survey, Fayetteville. 
Swanton, J.R.

1911 Indian Tribes of the Lower Mississippi Valley and Adjacent Coast of the Gulf of Mexico. Bureau of American Ethnology: Bulletin 43. Smithsonian: Washington, D.C.

Texas Historical Commission (THC)

2020 Texas Archeological Sites Atlas. Access-restricted online database. Texas Historical Commission. <https://atlas.thc.state.tx.us/>. Accessed February 12, 2020.

US Geological Survey (USGS)

1975 7.5-minute series topographic maps, Conroe, Texas, quadrangle.

2020 Texas Geology Web Map Viewer. <https://txpub.usgs.gov/txgeology/>. Accessed April 16, 2020.

Waters, M.R., S.L. Forman, T.A. Jennings, L.C. Nordt, S.G. Driese, J.M. Feinberg, J.L. Keene, J. Halligan, A. Lindquist, J. Pierson, C.T. Hallmark, M.B. Collins, and J.E. Wiederhold

2011 The Buttermilk Creek Complex and the Origins of Clovis at the Debra L. Friedkin Site, Texas. Science 331:1599-1603.

Wheat, J.B.

1953 The Addicks Dam Site. Bulletin 154:143-252. Bureau of American Ethnology, US Government Printing Office, Washington, D.C. 



\section{APPENDIX A:}

Shovel Test Data 

Intensive Cultural Resources Survey of the Proposed City of Conroe's

Stewarts Creek Wastewater System Improvements Project, Conroe, Montgomery County, Texas

Table A-1. Shovel Test Summary Data

\begin{tabular}{|c|c|c|c|c|c|}
\hline \multirow[b]{2}{*}{ ST No. } & \multicolumn{2}{|c|}{ UTM Coordinates ${ }^{1}$} & \multirow{2}{*}{$\begin{array}{l}\text { Depth } \\
\text { (cmbs) }\end{array}$} & \multirow[b]{2}{*}{ Soils } & \multirow[b]{2}{*}{ Artifacts } \\
\hline & Easting & Northing & & & \\
\hline CK01 & 265841 & 3353355 & $0-100+$ & $\begin{array}{l}\text { Mottled dark brown and yellowish- } \\
\text { brown sand }\end{array}$ & None \\
\hline CK02 & 265818 & 3353402 & $0-100+$ & $\begin{array}{l}\text { Mottled dark brown and yellowish- } \\
\text { brown sand }\end{array}$ & None \\
\hline CK03 & 265801 & 3353501 & $0-100+$ & $\begin{array}{l}\text { Mottled dark brown and yellowish- } \\
\text { brown sand }\end{array}$ & None \\
\hline CK04 & 265839 & 3353588 & $\begin{array}{c}0-10 \\
10-100+\end{array}$ & $\begin{array}{l}\text { Dark brown sandy loam } \\
\text { Mottled dark brown and yellowish- } \\
\text { brown sand }\end{array}$ & $\begin{array}{l}\text { None } \\
\text { None }\end{array}$ \\
\hline CK05 & 265908 & 3353661 & $\begin{array}{c}0-10 \\
10-100+\end{array}$ & $\begin{array}{l}\text { Dark brown sandy loam } \\
\text { Mottled dark brown and yellowish- } \\
\text { brown sand }\end{array}$ & $\begin{array}{l}\text { None } \\
\text { None }\end{array}$ \\
\hline CK07 & 265913 & 3353739 & $\begin{array}{l}0-80 \\
80+\end{array}$ & $\begin{array}{l}\text { Mottled dark brown and yellowish- } \\
\text { brown sand } \\
\text { Light gray clay sand }\end{array}$ & $\begin{array}{l}\text { None } \\
\text { None }\end{array}$ \\
\hline CK08 & 265909 & 3353866 & $\begin{array}{l}0-40 \\
40+\end{array}$ & $\begin{array}{l}\text { Mottled dark brown and yellowish- } \\
\text { brown sand } \\
\text { Light gray clay sand }\end{array}$ & $\begin{array}{l}\text { None } \\
\text { None }\end{array}$ \\
\hline CK09 & 265893 & 3353925 & $\begin{array}{l}0-80 \\
80+\end{array}$ & $\begin{array}{l}\text { Mottled dark brown and yellowish- } \\
\text { brown sand } \\
\text { Light gray clay sand }\end{array}$ & $\begin{array}{l}\text { None } \\
\text { None }\end{array}$ \\
\hline CK10 & 265882 & 3354078 & $\begin{array}{l}0-95 \\
95+ \\
\end{array}$ & $\begin{array}{l}\text { Mottled dark brown and yellowish- } \\
\text { brown sand } \\
\text { Light gray clay sand }\end{array}$ & $\begin{array}{l}\text { None } \\
\text { None }\end{array}$ \\
\hline CK11 & 265857 & 3354151 & $0-100+$ & $\begin{array}{l}\text { Mottled dark brown and yellowish- } \\
\text { brown sand }\end{array}$ & None \\
\hline CK12 & 265841 & 3354181 & $0-100+$ & $\begin{array}{l}\text { Mottled dark brown and yellowish- } \\
\text { brown sand }\end{array}$ & None \\
\hline CK13 & 265493 & 3354730 & $0-100+$ & $\begin{array}{l}\text { Mottled dark brown and yellowish- } \\
\text { brown sand }\end{array}$ & None \\
\hline CK14 & 265479 & 3354779 & $0-100+$ & $\begin{array}{l}\text { Mottled dark brown and yellowish- } \\
\text { brown sand }\end{array}$ & None \\
\hline CK15 & 265436 & 3354809 & $0-5$ & $\begin{array}{l}\text { Mottled dark brown and yellowish- } \\
\text { brown sand }\end{array}$ & None \\
\hline CK16 & 265446 & 3354862 & $0-5$ & $\begin{array}{l}\text { Mottled dark brown and yellowish- } \\
\text { brown sand }\end{array}$ & None \\
\hline CK17 & 265405 & 3354897 & $0-5$ & $\begin{array}{l}\text { Mottled dark brown and yellowish- } \\
\text { brown sand }\end{array}$ & None \\
\hline
\end{tabular}


Table A-1. Shovel Test Summary Data (cont.)

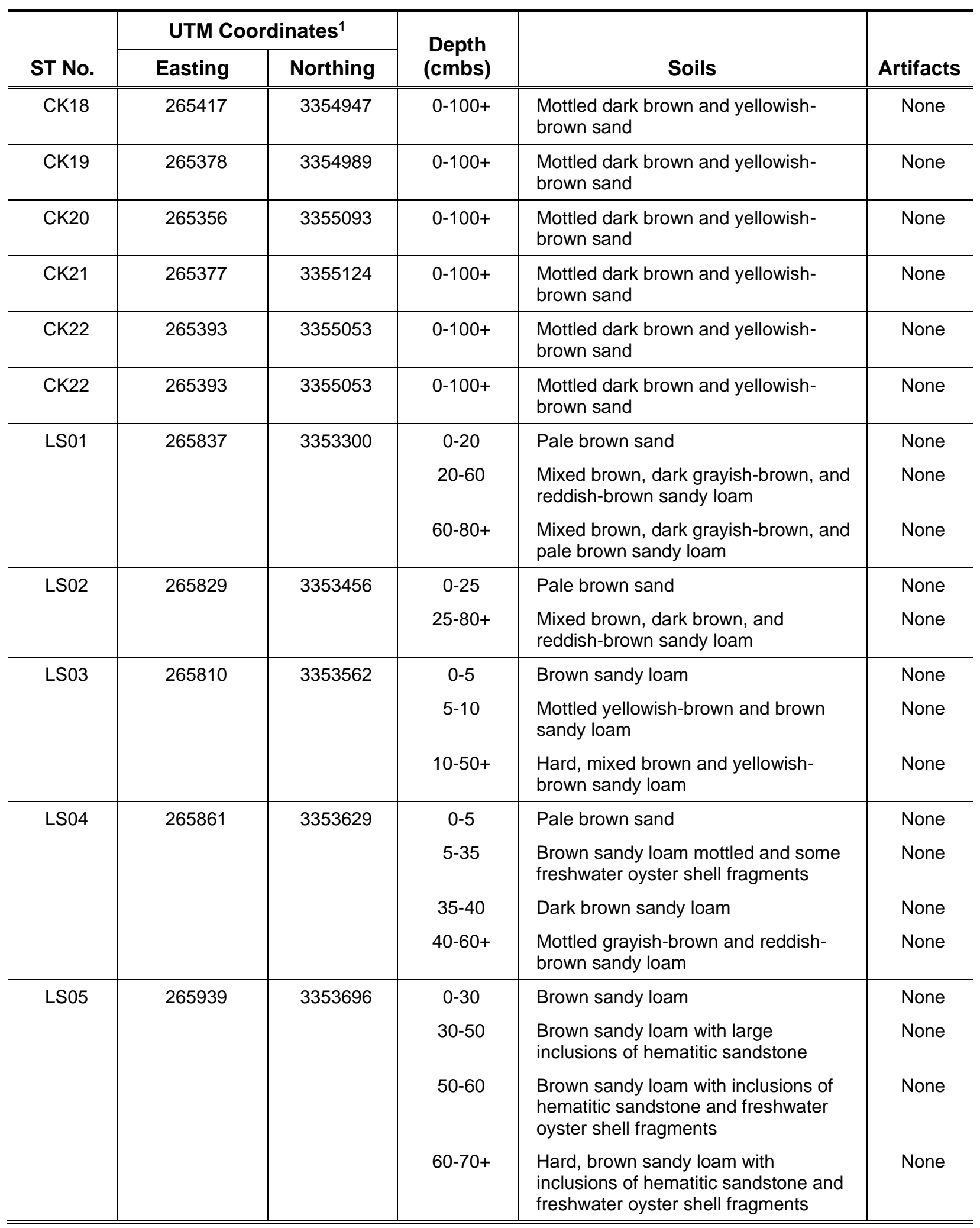


Intensive Cultural Resources Survey of the Proposed City of Conroe's

Stewarts Creek Wastewater System Improvements Project, Conroe, Montgomery County, Texas

Table A-1. Shovel Test Summary Data

\begin{tabular}{|c|c|c|c|c|c|}
\hline \multirow[b]{2}{*}{ ST No. } & \multicolumn{2}{|c|}{ UTM Coordinates $^{1}$} & \multirow{2}{*}{$\begin{array}{l}\text { Depth } \\
\text { (cmbs) }\end{array}$} & \multirow[b]{2}{*}{ Soils } & \multirow[b]{2}{*}{ Artifacts } \\
\hline & Easting & Northing & & & \\
\hline \multirow[t]{3}{*}{ LS06 } & \multirow[t]{3}{*}{265913} & \multirow[t]{3}{*}{3353799} & $0-5$ & Brown sandy loam & None \\
\hline & & & $5-30$ & $\begin{array}{l}\text { Mottled yellowish-brown and reddish- } \\
\text { brown sandy loam mixed with white } \\
\text { clay }\end{array}$ & None \\
\hline & & & $30-40+$ & $\begin{array}{l}\text { Mottled, dense white clay with } \\
\text { yellowish-brown }\end{array}$ & None \\
\hline \multirow[t]{2}{*}{ LS07 } & \multirow[t]{2}{*}{265890} & \multirow[t]{2}{*}{3353975} & $0-30$ & Brown sandy loam & None \\
\hline & & & $30-40+$ & $\begin{array}{l}\text { Very hard gray and reddish-brown } \\
\text { sandy loam }\end{array}$ & None \\
\hline \multirow[t]{2}{*}{ LS08 } & \multirow[t]{2}{*}{265891} & \multirow[t]{2}{*}{3354028} & $0-30$ & Brown sandy loam & None \\
\hline & & & $30-40+$ & $\begin{array}{l}\text { Mottled, very hard gray and reddish- } \\
\text { brown sandy loam }\end{array}$ & None \\
\hline \multirow[t]{2}{*}{ LS09 } & \multirow[t]{2}{*}{265881} & \multirow[t]{2}{*}{3354107} & $0-60$ & Light yellowish-brown sandy loam & None \\
\hline & & & $60-80+$ & Very hard yellowish-brown sandy loam & None \\
\hline LS10 & 265516 & 3354690 & $0-30$ & $\begin{array}{l}\text { Mixed yellowish-brown and grayish } \\
\text { brown sandy loam with red clay }\end{array}$ & None \\
\hline \multirow[t]{3}{*}{ LS11 } & \multirow[t]{3}{*}{265540} & \multirow[t]{3}{*}{3354654} & $0-40$ & Brown sandy loam & None \\
\hline & & & $40-45$ & $\begin{array}{l}\text { Mixed yellowish-brown, white, and } \\
\text { gray clay }\end{array}$ & None \\
\hline & & & $45-100_{+}$ & Light yellowish-brown sand & None \\
\hline \multirow[t]{2}{*}{ LS12 } & \multirow[t]{2}{*}{265559} & \multirow[t]{2}{*}{3354603} & $0-5$ & Dark brown sandy loam & None \\
\hline & & & $5-30+$ & Brown and light gray clay & None \\
\hline \multirow[t]{2}{*}{ LS13 } & \multirow[t]{2}{*}{265589} & \multirow[t]{2}{*}{3354562} & $0-5$ & Dark brown sandy loam & None \\
\hline & & & $5-30+$ & Brown and light gray clay & None \\
\hline LS14 & 265615 & 3354546 & $0-100+$ & Brown sandy loam & None \\
\hline LS15 & 265665 & 3354491 & $0-80+$ & $\begin{array}{l}\text { Mixed dark brown and yellowish-brown } \\
\text { sand }\end{array}$ & None \\
\hline LS16 & 265685 & 3354448 & $0-30+$ & $\begin{array}{l}\text { Mixed yellowish-brown and brown } \\
\text { sandy loam with red clay }\end{array}$ & None \\
\hline LS17 & 265716 & 3354437 & $0-5+$ & $\begin{array}{l}\text { Mottled brown and dark brown sandy } \\
\text { loam }\end{array}$ & None \\
\hline LS18 & 265725 & 3354383 & $0-5+$ & $\begin{array}{l}\text { Mottled brown and dark brown sandy } \\
\text { loam }\end{array}$ & None \\
\hline LS19 & 265760 & 3354344 & $0-5+$ & $\begin{array}{l}\text { Mottled brown and dark brown sandy } \\
\text { loam }\end{array}$ & None \\
\hline LS20 & 265792 & 3354298 & $0-30+$ & $\begin{array}{l}\text { Mixed yellowish-brown and brown } \\
\text { sandy loam with red clay }\end{array}$ & None \\
\hline
\end{tabular}




\section{Table A-1. Shovel Test Summary Data}

\begin{tabular}{|c|c|c|c|c|c|}
\hline \multirow[b]{2}{*}{ ST No. } & \multicolumn{2}{|c|}{ UTM Coordinates ${ }^{1}$} & \multirow{2}{*}{$\begin{array}{c}\text { Depth } \\
\text { (cmbs) }\end{array}$} & \multirow[b]{2}{*}{ Soils } & \multirow[b]{2}{*}{ Artifacts } \\
\hline & Easting & Northing & & & \\
\hline LS21 & 265820 & 3354250 & $0-30+$ & $\begin{array}{l}\text { Mixed yellowish-brown and brown } \\
\text { sandy loam with red clay }\end{array}$ & None \\
\hline LS22 & 265818 & 3354219 & $\begin{array}{c}0-20 \\
20-40+\end{array}$ & $\begin{array}{l}\text { Yellowish-brown sandy loam } \\
\text { Mottled gray sandy clay with yellowish- } \\
\text { brown and light yellowish brown sandy } \\
\text { loam }\end{array}$ & $\begin{array}{l}\text { None } \\
\text { None }\end{array}$ \\
\hline & & & $40-50+$ & White sand & None \\
\hline
\end{tabular}

1 All UTM coordinates are located in Zone 15 and utilize the North American Datum of 1983 (NAD 83). cmbs = Centimeters below surface

ST $=$ Shovel test

UTM = Universal Transverse Mercator 